\title{
Fiscal Policies AND Business CyCLES IN AN ENLARGED EURO AREA
}

\author{
KARSTEN STAEHR
}

CESIFO WORKING PAPER No. 1933

CATEgory 5: Fiscal Policy, Macroeconomics AND Growth

FEBRUARY 2007

An electronic version of the paper may be downloaded

- from the SSRN website:

- from the RePEc website:

www.SSRN.com

Www.RePEc.org

- from the CESifo website: www.CESifo-group.de 


\title{
FisCAL POLICIES AND BUSINESS CYCLES IN AN ENLARGED EURO AREA
}

\begin{abstract}
This paper compares the cyclical properties of fiscal policies across the 12 original eurozone countries and the future members from Central and Eastern Europe. For the sample period 1995-2005, the fiscal balance exhibits less inertia and is more counter-cyclical in Central and Eastern European countries than in members of the eurozone. The main differences arise from the revenue side. Differences in the formation of fiscal policy between current and future eurozone countries decrease over time. Autonomous fiscal policy has little or no effect on cyclical variability in either of the two groups of countries. Counter-cyclical fiscal policy appears to be effective in Central and Eastern European countries, but largely ineffective in eurozone countries.
\end{abstract}

JEL Code: E62, E63, E32.

Keywords: fiscal policy determinants, fiscal policy effects, eurozone expansion.

\author{
Karsten Staehr \\ Research Department \\ Bank of Estonia \\ Estonia pst 13 \\ 15095 Tallinn \\ Estonia \\ karsten.staehr@epbe.ee \\ karsten.staehr@ut.ee
}

30 January 2007

The author would like to thank David Mayes, Egle Tafenau and numerous colleagues at the Estonian Central Bank for useful comments and suggestions. The author has also benefited from comments by the discussant, Evzen Kocenda, and other workshop participants at the CESifo workshop "Euro-Area Enlargement", 24 November 2006. All remaining errors and omissions are the responsibility of the author. The views expressed are those of the author and do not represent the official views of the Bank of Estonia. 


\section{Introduction}

The 12 countries that became members of the European Union on, respectively, 1 May 2004 and 1 January 2007 have committed themselves to joining the European Monetary Union (EMU) in due course. This will bring countries that have recently emerged from central planning and widespread economic repression into the EMU. This paper seeks to advance our understanding of fiscal policies in these countries and shed light on possible differences between the original 12 members of the eurozone and the future members from Central and Eastern Europe. ${ }^{1}$

The conduct of fiscal policy has been one of the most contentious issues in the operation of the EMU. Fiscal policy issues are also likely to play a major role in future years as new EU members join the eurozone. The question is therefore which fiscal policy challenges transition countries are going to experience before and after entering the eurozone and, correspondingly, which challenges can the eurozone expect. While the formation and effectiveness of fiscal policies have been well researched for the 15 "old" EU countries, relatively few studies have considered these issues for the new EU members, and no studies have used econometric methods to compare fiscal policies across the existing and future members of the eurozone.

This paper builds on a panel dataset with a large number of variables from $27 \mathrm{EU}$ members across 11 years. The main line of inquiry is to examine possible differences in the functioning of fiscal policies across the existing eurozone members and the countries that will join the eurozone in the coming years. Two key questions are addressed. First, are the cyclical properties of fiscal policy different across the existing and future eurozone members? Are policies counter-cyclical, a-cyclical or pro-cyclical, and how do they differ across these groups of countries? Second, what are the effects of fiscal policies on economic fluctuations in the eurozone and for the future members? Do fiscal policies reduce economic fluctuations, aggravate fluctuations or are they largely ineffective?

The first question relates to the fulfilment of the deficit requirement of the Maastricht criteria stating that the deficit cannot exceed 3\% of GDP except in extraordinary circumstances. The criterion is also present in the Stability and Growth Pact (SGP), which applies to countries inside the European Monetary Union. If fiscal policies are strongly counter-cyclical, the risk of breaking the $3 \%$ limit may be large during downturns. In other words, strong countercyclicality may pose a serious challenge when a country is seeking EMU membership, but possibly also after having achieved membership.

The second question relates to the prevalence of cyclical output fluctuations for EMU members. A country that has joined the eurozone cannot pursue monetary or exchange rate policies independently in case an asymmetric shock affects the economy adversely. In this situation, fiscal policy becomes the main policy tool for stabilising output fluctuations. As an introduction to the SGP, the European Commission (2006) states: "[I]t was also recognised that the loss of the exchange rate instrument in EMU would imply a greater role for automatic fiscal stabilisers at national level to help economies adjust to asymmetric shocks".

The scope of macroeconomic stabilisation is important for assessing what constitutes an optimal currency area (OCA) and whether the 12 original members of the EMU constitute such

\footnotetext{
${ }^{1}$ Slovenia joined the EMU on 1 January 2007 and thus became the first country from Central and Eastern Europe to enter the eurozone. In this paper, Slovenia is included in the group of future eurozone members as data for the empirical analysis is only available until 2005.
} 
an area. The theory on optimal currency areas outlines conditions under which countries participating in a currency union would not experience excessive output and employment instability when subject to asymmetric shocks. It is common to point to labour and capital mobility, price and wage flexibility and the mechanism for fiscal transfers across the member countries (Baldwin \& Wyplosz 2004). It is important to emphasise that the economies of countries participating in a currency union will adapt to the changed macroeconomic conditions; this implies that the degree of fulfilment of the OCA criteria is endogenously determined (Frankel \& Rose 1998).

As stated, asymmetric shocks might be of less importance if the fiscal policy is countercyclical and effective in reducing output and employment fluctuations (Ardy et al. 2006, ch. $2)^{2}$ A fiscal policy reducing real economic variability needs not involve inter-constituency transfers, but rather the intertemporal reallocation of government spending and taxation within each country.

There is extensive literature discussing whether the expanded European Union constitutes an optimal currency area and, in particular, whether the business cycles across the member countries are converging; see, for example, Korhonen (2003) and Frenkel \& Nickel (2005). The importance of fiscal policies in the EMU and the effect of the SGP on fiscal policy and economic fluctuations have been widely discussed; see, for example, Wyplosz (2002), Ballabriga \& Martinez-Mongay (2003), Fatas \& Mihov (2003b), Annett \& Jaeger (2004), Ardy et al. (2006) and Buti \& Sapir (2006).

Relatively little has been written on fiscal policy challenges stemming from the expansion of the eurozone to include the former transition countries of Central and Eastern Europe. ${ }^{3}$ This applies in particular to the formation of fiscal policy and its effects across an expanded eurozone. Nuti (2006) discusses fiscal policy in the new EU member states and argues that the Maastricht criteria and the SGP represent undue constraints on these rapidly developing countries. Berger et al. (2007) argue that the differences in the overall fiscal stance of the Central European accession countries can be explained by the bargaining position of the countries visà-vis the other EU countries with respect to the fulfilment of the Maastricht criteria. Afonso et al. (2005) analyse cases of fiscal consolidation in the CEE countries and seek to determine factors leading to a permanent improvement of the fiscal balance. Kattai \& Lewis (2005) estimate fiscal policy reactions for individual countries in Central and Eastern Europe.

The issues analysed in this paper are important for new EU countries seeking to join the EMU in the future. The issues are, however, also important in their own right, i.e. even if the countries do not become eurozone members in the immediate future. Several issues are noteworthy.

First, the improvement of the management of fiscal policy and its integration with other policies require that fiscal policy formation be analysed and evaluated. It is of particular interest to understand the economic and political factors affecting, respectively, the cyclical properties of fiscal policy and the prevalence of autonomous or non-systematic discretionary fiscal pol-

\footnotetext{
2 Ardy et al. (2006, ch. 2) list three different areas from which tensions can arise if a common macroeconomic policy is sought, i.e. that policymakers have different preferences, that countries are hit by different shocks and that the effect of shocks and policy instruments vary across countries.

${ }^{3}$ Budina \& van Wijnbergen (1997) present a study of fiscal policy in Central and Eastern Europe during the early transition phase.
} 
icy. ${ }^{4}$ Recent empirical studies include Roubini \& Sachs (1989), Alesina \& Perotti (1995, 1997) and Fatas \& Mihov (2003a); none of these consider the post-communist transition economies in any detail.

Second, the effectiveness of fiscal policy in stabilising cyclical fluctuations in output and employment is important in so far as fluctuations affect social welfare. Theory provides a range of hypotheses to be tested, e.g. the Keynesian fiscal multiplier, the Ricardian equivalence hypothesis and tax smoothing across the cycle (Romer 2005, chs. 5, 7, 11). Empirically, the joint endogeneity of fiscal policy and output performance necessitates the use of challenging methods to ensure identification, e.g. natural experiments, VAR-models or various forms of instrumental variables estimation. ${ }^{5}$ The studies reach rather conflicting results with respect to the effect of fiscal policy, presumably because they use different definitions for fiscal policy variable(s) and consider different countries and time horizons.

Third, there is an increasing body of evidence suggesting that macroeconomic stability can contribute to higher long-term growth; see e.g. Fischer (1993) and Fatas \& Mihov (2005). Aghion \& Howitt (2006) argue that short-term output volatility leads to a lower trend growth rate in countries with less developed financial markets: in a neo-Schumpeterian growth setting, economic fluctuations lead to too many firm exits if capital and insurance markets are imperfect. The upshot is that policies reducing economic fluctuations may also enhance growth. This claim is supported by empirical evidence assessing growth in 17 OECD countries over the period 1965-2001.

The remainder of this paper is structured as follows. Section 2 provides a brief overview of fiscal policies in Western and Eastern Europe since the early 1990s. Section 3 assesses factors determining the fiscal policy reactions in, respectively, the current and future eurozone members. Section 4 considers the effect of fiscal policy measures on output fluctuations. Finally, Section 5 summarises and discusses some policy implications.

\section{Fiscal policies in current and future eurozone countries}

The two regions in Europe faced different fiscal policy challenges during the eventful years following the reunification of Germany, the political integration of Western Europe and the emergence of Eastern European countries as market-based democracies. This section reviews briefly the fiscal policy developments in Europe since 1990.

Our sample comprises a total of 27 European countries: the 12 eurozone countries, the three old EU countries outside the eurozone (Denmark, Sweden and the UK), the 10 new EU member countries from Central and Eastern Europe, as well as Malta and Cyprus. ${ }^{6}$ The applicant countries Croatia, Macedonia and Turkey are not included in the sample.

The statistical analysis relies mainly on data from Eurostat (see Appendix A for detailed variable descriptions and sources). There are some missing observations especially for the transi-

\footnotetext{
${ }^{4}$ Changes in autonomous (or non-systematic discretionary) fiscal policy are changes that cannot be explained by cyclical developments in the economy or other easily observable factors (Gali \& Perotti 2003).

${ }^{5}$ Important studies considering the effect of automatic stabilisers, counter-cyclical fiscal policies and/or other forms of fiscal policies include Aschauer (1985) and more recently Cohen \& Follette (2000), Fatas \& Mihov (2001), Blanchard \& Perotti (2002), Perotti (2005), Caldara \& Kamps (2006) and Bayomi \& Sgheri (2006).

${ }^{6}$ Some data series for Malta and Cyprus are quite volatile and often available for short time periods only.
} 
tion countries in the early years of the sample and for Malta and Cyprus. Attempts to extend the data series backwards have been unsuccessful. We tried to include data on government finances from the Government Financial Statistics of the IMF and from the Transition Reports of the EBRD, but both the level and the dynamics of the series generally differ markedly from the Eurostat data. Overall, the data series from Eurostat is reckoned to be consistent across countries and of acceptable quality.

The Maastricht Treaty, signed in February 1992, constitutes the legal foundation for deeper cooperation within the (relabelled) European Union. A cornerstone was the establishment of the European Monetary Union with a shared currency and a common monetary policy (Wyplosz 2006, Buti \& Sapir 2006). The Maastricht Treaty spelled out a set of convergence criteria, which all prospective member countries - in principle - had to fulfil before being admitted. ${ }^{7}$ The Maastricht criteria involved requirements on inflation, long-term interest rates and exchange rate stability. In addition, two of the criteria constitute restrictions on government finances, i.e. that the general government deficit cannot exceed 3\% of GDP, save in exceptional circumstances, and that the government gross debt stays within $60 \%$ of GDP or has been approaching the $60 \%$ ceiling at a satisfactory pace.

The Stability and Growth Pact requires that the countries participating in the EMU maintain fiscal coefficients within the limits of the Maastricht Treaty. The SGP was decided in December 1996 and stipulated that a country breaching the 3\% deficit ceiling would be subject to an excessive deficit procedure unless one or more "relevant factors" explained the deficit. A revised SGP from March 2005 makes the rules concerning the use of the excessive deficit procedure more flexible.

The 1990s became a period where governments in most EU countries strived to satisfy particularly the fiscal criteria of the Maastricht Treaty. In May 1998, the heads of the EU countries came to the decision that 11 countries satisfied the criteria, and the euro was launched on 1 January 1999 followed by euro-denominated banknotes and coins on 1 January 2002. In June 2000, the accession of Greece to the EMU was approved as from 1 January 2001. The downturn in the European economies after the bursting of the tech bubble in 2000-01 strained government finances, especially in the large, core EMU countries.

The countries in Central and Eastern Europe faced numerous challenges in the 1990s. Most of them gained or regained independence and had to build up new national government finance systems. The transition to a market economy and the deep recessions in the early 1990s strained budget balances (Budina \& van Wijnbergen 1997). A number of CEE countries experienced financial crises. For many CEE countries the Russian crisis in the fall of 1998 led to a significant trade contraction, financial instability and growth setbacks.

Table 1 shows the annual GDP growth (GY) for three groups of countries. The Eurozone 12 group comprises the 11 countries that became EMU members in 1999 and Greece, which entered in 2001. The group Denmark, Sweden \& UK consists of the three old EU members that did not join the EMU. The CEE10 group is made up of the 10 countries from Central and Eastern Europe that joined the EU in May 2004 and January 2007. The different growth experiences across the old and new EU members become particularly apparent after 1999, when growth stagnated in the groups of Western European countries (Eurozone 12 and Denmark, Sweden \& UK, while it accelerated in the group of CEE10 countries.

\footnotetext{
${ }^{7}$ It is clear, however, that one-off measures, short-term asset transfers and "creative bookkeeping" enabled a number of especially Southern European countries to meet the Maastricht criteria (Nuti 2006).
} 
Table 1. Annual GDP growth as a percent (GY), unweighted averages for country groups, 1995-2005

\begin{tabular}{lrrrrrrrrrrr}
\hline & $\mathbf{1 9 9 5}$ & $\mathbf{1 9 9 6}$ & $\mathbf{1 9 9 7}$ & $\mathbf{1 9 9 8}$ & $\mathbf{1 9 9 9}$ & $\mathbf{2 0 0 0}$ & $\mathbf{2 0 0 1}$ & $\mathbf{2 0 0 2}$ & $\mathbf{2 0 0 3}$ & $\mathbf{2 0 0 4}$ & $\mathbf{2 0 0 5}$ \\
\hline Eurozone 12 & 5.5 & 2.7 & 4.2 & 4.1 & 4.4 & 4.8 & 2.4 & 1.9 & 1.6 & 2.7 & 2.1 \\
\hline Denmark, Sweden \& UK $^{2}$ & 3.3 & 2.3 & 2.9 & 3.0 & 3.4 & 3.9 & 1.3 & 1.5 & 1.6 & 2.9 & 2.5 \\
\hline CEE10 $^{\text {a) }}$ & 3.0 & 2.8 & 4.6 & 4.1 & 2.1 & 4.6 & 4.5 & 4.5 & 5.2 & 6.2 & 6.3
\end{tabular}

a) No data available for the Czech Republic and Bulgaria for 1995 and for Romania for 1995-98. Source: Eurostat (2006), own calculations.

Table 2 shows the general budget balance as a percent of gross domestic product (BAL) for the three groups of countries. The average budget balance for the period 1995-2005 (or available sample years) is $-2.2 \%$ of GDP for the eurozone countries, $0 \%$ for Denmark, Sweden \& UK and $-2.8 \%$ for the 10 new EU members from Central and Eastern Europe. There are considerable differences across the countries within each group, cf. the country-specific data reported in Appendix B.

Table 2. General government balance as a percentage of GDP (BAL), unweighted averages for country groups, 1995-2005

\begin{tabular}{lrrrrrrrrrrr}
\hline & $\mathbf{1 9 9 5}$ & $\mathbf{1 9 9 6}$ & $\mathbf{1 9 9 7}$ & $\mathbf{1 9 9 8}$ & $\mathbf{1 9 9 9}$ & $\mathbf{2 0 0 0}$ & $\mathbf{2 0 0 1}$ & $\mathbf{2 0 0 2}$ & $\mathbf{2 0 0 3}$ & $\mathbf{2 0 0 4}$ & $\mathbf{2 0 0 5}$ \\
\hline Eurozone 12 $^{\text {a) }}$ & -4.4 & -3.5 & -1.7 & -1.0 & -0.4 & 0.8 & -0.5 & -1.2 & -1.8 & -1.8 & -1.6 \\
\hline Denmark, Sweden \& UK & -5.3 & -3.0 & -1.1 & 0.7 & 2.0 & 3.5 & 1.9 & -0.2 & -0.7 & 0.4 & 1.4 \\
\hline CEE10 $^{\text {b) }}$ &.. &.. & -2.9 & -2.9 & -3.5 & -3.3 & -3.0 & -3.4 & -2.6 & -1.9 & -1.8 \\
\hline
\end{tabular}

a) No data available for Spain for 1995-96.

b) No data available for Latvia and Hungary for 1997-98 and for Bulgaria and Romania for 2005.

Source: Eurostat (2006), own calculations.

For the eurozone countries, the years before the turn of the century comprised a period of rapid fiscal consolidation. It is noteworthy, however, that the group of EU countries not participating in the EMU underwent a similar consolidation during the same period. ${ }^{8}$ The fiscal position has deteriorated in both EMU and non-EMU countries since the turn of the century, and 2000 remains the only year in the sample in which the EMU countries on average attained a positive budget balance.

Fiscal policies in the Central and Eastern European countries have generally led to larger deficits than experienced in the eurozone countries and the group comprising Denmark, Sweden and the UK. The Visegrad countries have pursued policies that in some years have led to substantial headline deficits. Fiscal policies in the Baltic States and Bulgaria have been restrained by the fixed exchange rate policies pursued in these countries (Mueller et al. 2002, Grigonyte 2003).

Table 3 shows that the general government debt stock as a percentage of GDP (DEBT) fell in the eurozone countries until 2002, but has remained stable since. The average debt burden in the new EU countries from Central and Eastern Europe is less than half the level in the old EU countries. In spite of substantial deficits, the government debt burden in the region has remained stable partly as a result of relatively rapid GDP growth.

\footnotetext{
${ }^{8}$ This sheds some doubt on the widely asserted claim that although the Maastricht criteria may be somewhat arbitrary, the criteria contributed to an increased focus on prudence and economic stability in fiscal policymaking (Buti \& Sapir 2006, Afxentiou 2000). Still, individual countries, such as Italy and Greece, did exhibit a substantial fiscal consolidation during the 1990s.
} 
Table 3. Government consolidated gross debt as a percentage of GDP (DEBT), unweighted averages for country groups, 1995-2005

\begin{tabular}{lcccccccccccc}
\hline & $\mathbf{1 9 9 5}$ & $\mathbf{1 9 9 6}$ & $\mathbf{1 9 9 7}$ & $\mathbf{1 9 9 8}$ & $\mathbf{1 9 9 9}$ & $\mathbf{2 0 0 0}$ & $\mathbf{2 0 0 1}$ & $\mathbf{2 0 0 2}$ & $\mathbf{2 0 0 3}$ & $\mathbf{2 0 0 4}$ & $\mathbf{2 0 0 5}$ \\
\hline Eurozone 12 & 74.8 & 74.4 & 71.6 & 68.5 & 67.0 & 64.8 & 63.7 & 61.9 & 61.7 & 61.5 & 61.6 \\
\hline Denmark, Sweden \& UK & 73.1 & 72.6 & 69.7 & 66.6 & 64.6 & 61.6 & 60.4 & 58.6 & 58.4 & 58.2 & 57.9 \\
\hline CEE10 $^{\text {b) }}$ &.. &.. & 29.2 & 25.4 & 28.6 & 28.6 & 29.4 & 29.7 & 30.5 & 30.0 & 28.8
\end{tabular}

a) Estimates by Eurostat.

b) No data available for Latvia and Slovenia for 1995-98 and for Bulgaria and Romania for 2005.

Source: Eurostat (2006), own calculations.

One main conclusion follows from the descriptive review in this section, namely that the Eurozone 12 countries and the new EU members - when taken as groups - have experienced very different fiscal policy trends and business cycles since 1995. It is also clear that there is substantial variation across the countries in the two groups. These considerations lead to the question whether the different developments are also reflected in the way fiscal policy is formed and functions in the two groups.

\section{The cyclical reaction of fiscal policy}

This section analyses how different factors have affected fiscal policy variables in the original 12 eurozone countries and the 10 new EU countries from Central and Eastern Europe. We estimate fiscal policy reaction functions, which explain the fiscal policy stance by policy inertia, economic fluctuations and different variables reflecting debt-servicing requirements. A number of recent studies estimate such fiscal policy rules to ascertain, e.g. the cyclicality of fiscal policies (Fatas \& Mihov 2001, Gali \& Perotti 2003 and Ballabriga \& Martinez-Mongay 2003).

The main objective is to assess whether the reaction functions of the CEE countries differ from those of the eurozone countries. The short time dimension of the sample necessitates the use of panel data estimation. Estimations of reaction functions for each country would lead to unreliable results. We estimate separate coefficients for, respectively, the eurozone countries and the CEE countries and then compare the results across the two groups of countries. An essentially similar approach is used in Gali \& Perotti (2003) and Wyplosz (2006) to assess changes over time.

The choice of the two groups is based on a number of factors. First, as described in Section 2, the countries within each of the two groups have faced a number of similar challenges (EMU qualification and SGP vs. post-transition adjustment). Second, the economic structure varies markedly across the two groups (high-income service economies vs. lower-income manufacturing economies). Third, the operation of the EMU implies that the common monetary policy has throughout most of the sample period been determined in co-operation between the 12 original eurozone countries, while the stabilisation policies in the CEE countries have not been constrained by similar institutional arrangements. Ultimately, the appropriateness of the choice of groups rests on empirical testing - a point that will be returned to below. 


\subsection{Inertia and cyclicality}

Table 4 shows the results of estimating reaction functions for the general government deficit as a percentage of GDP under different assumptions and using different estimation techniques.

Column (4.1) shows the results when BAL, the general government balance as a percentage of GDP, is regressed on the one year lagged government balance (BAL(-1)), the contemporaneous percentage change in output (GY), and the one year lagged debt stock as a percentage of GDP (DEBT(-1)) as well as country- and time-specific dummies. The separate effects of the explanatory variables for the two groups of countries are traced by interacting the explanatory variables with country group dummies. In specific, each of the explanatory variables is multiplied by the dummy variables $W$ and $E$. The dummy $W$ is equal to 1 for the Eurozone 12 countries and otherwise 0; the dummy $E$ is equal to 1 for the 10 Central and Eastern European countries and otherwise $0 .{ }^{9}$

The estimations include GY as a proxy for the cyclical stance. Clearly, the countries in the sample have different "natural rates" or trend growth rates, and it might thus have been useful to include the deviation from trend growth instead of the actual growth rate in the regressions. Different methods for estimating the trend growth rate give differing and often inaccurate results and are only known precisely with a very long lag (Hallett et al. 2007). Thus, with only 11 years of annual data, it is reasonable to use the average growth rate during the period to approximate the trend growth rate. This assumption implies that changes in the output growth rate should be interpreted as changes in the output gap. ${ }^{10}$ The assumption of a constant trend growth rate during the 11 years of the sample necessitates the use of country fixed effects (or equivalent) in all estimations.

OLS estimation of dynamic panels with a lagged endogenous variable as an explanatory variable generally leads to inconsistent coefficient estimates, even when cross-section fixed effects are used (Green 2000, ch. 14; Arellano 2003, chs. 7-8). Instead, we employ the Difference GMM Arellano-Bond one-step estimator (GMM-AB). The regression is timedifferenced in order to remove cross-section specific effects and the differenced regression is then estimated using GMM with correctly lagged levels of the endogenous variable and nonexogenous explanatory variables as instruments (together with other suitable instruments). The Arellano-Bond estimator is consistent (although biased in small samples); its efficiency depends on the characteristics of the sample (Judson \& Owen 1999).

The specific choice of instruments for the differenced equation requires careful consideration (Murray 2006). The lagged budget balance is instrumented using the two periods lagged level. The explanatory variable GY (contemporaneous output growth) may be affected by fiscal policy, which would lead GY to be correlated with the residual. Additionally, the GDP level is used to scale both the fiscal balance and the change in GDP. GY is therefore instrumented using its two periods lagged level as an instrument. The differencing of the debt variable and the scaling with the GDP imply that the pre-determined debt stock should also be instrumented;

\footnotetext{
${ }^{9}$ The panel estimation for column (4.1) is thus: BAL $=\alpha_{1} \cdot \mathrm{BAL}(-1) \cdot W+\alpha_{2} \cdot \mathrm{BAL}(-1) \cdot E+\alpha_{3} \cdot \mathrm{GY} \cdot W+\alpha_{4} \cdot \mathrm{GY} \cdot E+$ $\alpha_{5} \cdot \operatorname{DEBT}(-1) \cdot W+\alpha_{6}$.DEBT(-1).E $+\Sigma \beta_{i} \cdot$ country dummy $+\Sigma \gamma_{j} \cdot$ time dummy + error term, where Greek letter coefficients that are to be estimated.

${ }^{10}$ Some experiments using output gaps published by the IMF (World Economic Outlook Database) for some eurozone countries yielded mixed results. For some countries the results were essentially unchanged if GY were replaced by the change in the output gap, while for others (especially Germany) the difference was noticeable.
} 
its two period lagged level is chosen as an instrument. To increase efficiency, the number of level instruments can be increased, as additional predetermined values are available for the later years of the estimation sample. We have, however, chosen to abstain from using such dynamic instrumentation. First, the information content of level variables that are lagged more than two periods is likely to be limited. Second, the simple lag structure of the instruments makes it easier to retain the same instruments across different sub-divisions of the sample (country groups, time periods). "Outside instruments" are included in the form of output growth in the USA, output growth in Russia, real oil price growth, and the real Fed funds interest rate. These variables are deemed unaffected by developments in individual countries in the sample. The instruments are included separately for the group of Western European countries $(W)$ and the group of Central and Eastern European countries $(E)$.

Table 4. Budget balance reaction functions

\begin{tabular}{|c|c|c|c|c|c|}
\hline & $(4.1)$ & $(4.2)$ & $(4.3)$ & $(4.4)$ & $(4.5)$ \\
\hline & BAL & BAL & BAL & BAL & BAL \\
\hline BAL $(-1) \cdot W$ & $\begin{array}{l}0.606^{* * *} \\
(0.141)\end{array}$ & $\begin{array}{l}0.725^{* * *} * \\
(0.052)\end{array}$ & $\begin{array}{l}0.621 * * * \\
(0.080)\end{array}$ & $\begin{array}{l}0.586 * * * \\
(0.136)\end{array}$ & $\begin{array}{l}0.596^{* * * *} \\
(0.145)\end{array}$ \\
\hline BAL $(-1) \cdot E$ & $\begin{array}{l}0.099 \\
(0.131)\end{array}$ & $\begin{array}{l}0.084^{*} \\
(0.092)\end{array}$ & $\begin{array}{l}0.177 * * \\
(0.072)\end{array}$ & $\begin{array}{c}0.099 \\
(0.116)\end{array}$ & $\begin{array}{c}0.244 * \\
(0.137)\end{array}$ \\
\hline $\mathbf{G Y} \cdot \boldsymbol{W}$ & $\begin{array}{l}0.218 * * \\
(0.093)\end{array}$ & $\begin{array}{l}0.189 * \\
(0.104)\end{array}$ & $\begin{array}{l}0.193 * * * \\
(0.059)\end{array}$ & $\begin{array}{l}0.268 * * \\
(0.123)\end{array}$ & .. \\
\hline $\mathrm{GY} \cdot \boldsymbol{E}$ & $\begin{array}{l}0.622 * * * \\
(0.146)\end{array}$ & $\begin{array}{l}0.593 * * * \\
(0.135)\end{array}$ & $\begin{array}{l}0.457 * * * \\
(0.103)\end{array}$ & $\begin{array}{l}0.496 * * * \\
(0.149)\end{array}$ & .. \\
\hline GYP·W & .. & .. & .. & .. & $\begin{array}{l}0.231 * * \\
(0.090)\end{array}$ \\
\hline GYP $\cdot E$ & .. & .. & .. & .. & $\begin{array}{l}0.363^{* * *} \\
(0.059)\end{array}$ \\
\hline $\operatorname{DEBT}(-1) \cdot W$ & $\begin{array}{l}-0.013 \\
(0.022)\end{array}$ & $\begin{array}{l}0.0090 \\
(0.028)\end{array}$ & $\begin{array}{l}-0.011 \\
(0.0089)\end{array}$ & $\begin{array}{c}0.027 \\
(0.032)\end{array}$ & $\begin{array}{c}0.056 \\
(0.024)\end{array}$ \\
\hline $\operatorname{DEBT}(-1) \cdot E$ & $\begin{array}{r}0.014 \\
(0.030) \\
\end{array}$ & $\begin{array}{r}0.034 \\
(0.027) \\
\end{array}$ & $\begin{array}{l}-0.0073 \\
(0.023) \\
\end{array}$ & $\begin{array}{c}0.025 \\
(0.031) \\
\end{array}$ & $\begin{array}{l}0.110 * * \\
(0.052)\end{array}$ \\
\hline Country dummies & Yes & Yes & Yes & Yes & Yes \\
\hline Year dummies & Yes & No & Yes & Yes & Yes \\
\hline Method & GMM-AB ${ }^{a)}$ & GMM-AB $^{\mathrm{a})}$ & OLS/FE & GMM-AB $^{\mathrm{a})}$ & $\mathrm{GMM}^{-\mathrm{AB}^{\mathrm{b}}}$ \\
\hline Time sample & $95-05$ & $95-05$ & $95-05$ & $95-05$ & $95-05$ \\
\hline No. of countries & 22 & 22 & 22 & 27 & 22 \\
\hline No. of obs. & 194 & 194 & 205 & 239 & 188 \\
\hline
\end{tabular}

The baseline estimation in (4.1) suggests that the eurozone countries and the future member countries exhibit very different fiscal policy reaction functions: a Wald test at the 5\%-level rejects the joint null hypothesis that the coefficients to BAL(-1) $W$ and $\mathrm{BAL}(-1) \cdot E$, to $\mathrm{GY} \cdot W$ and $\mathrm{GY} \cdot E$ and to $\operatorname{DEBT}(-1) \cdot W$ and $\operatorname{DEBT}(-1) \cdot E$ are pair-wise equal. In other words, the coefficients to the explanatory variables of the eurozone countries differ significantly from the coefficients of the CEE countries. 
The budget balance in the old eurozone countries exhibits substantial inertia, while this is much less prevalent in the future eurozone members from Central and Eastern Europe. A Wald test at the 5\%-level rejects the null hypothesis that the coefficients to BAL(-1).W and BAL(-1) $E$ are identical.

The sensitivity of the budget balance to output shocks also differs markedly across the two groups of European countries. The coefficients to GY.W and GY.E are both positive and significant at the 5\%-level, but the former coefficient is much smaller than the latter. In the sample period, fiscal policies in the CEE countries have on average been more counter-cyclical (or reactive) than in the eurozone countries. In the CEE countries, a 1\%-point fall in output growth has on average been associated with a $0.5 \%$-point deterioration of the budget balance (expressed as a percentage of GDP). The results for the eurozone countries are broadly in line with earlier studies (Ballabriga \& Martinez-Mongay 2003, Wyplosz 2006). This suggests that the results for the CEE are reliable although no directly comparable studies exist for these countries.

The coefficients for the lagged debt stock are not significantly different from zero for any of the two country groups. A higher debt stock, which leads to higher interest payments, affects the overall balance in two ways: the extra interest payments lead directly to a deterioration of the overall balance, but this might bring about a compensatory change in the primary balance. These issues are addressed in more detail below.

The results presented in (4.1) are robust to changes in the specification and in estimation methods. Column (4.2) shows that the results are largely unchanged when the year dummies are removed. In (4.3), the Arellano-Bond GMM estimation method is replaced by ordinary OLS with country and year fixed effects (OLS/FE). ${ }^{11}$ The estimation method apparently makes little qualitative difference in this case. We also experimented with different instrumentation configurations and found that the choice of instruments affects the results to only a small extent. Column (4.4) shows the results when the three old EU members, Denmark, Sweden, the UK, as well as Malta and Cyprus are added to the $W$ group of countries. The changes are small.

The estimations in (4.1), (4.2) and (4.4) use instrumental variables to eliminate or reduce a possible simultaneity bias stemming from "reverse causality", i.e. from fiscal policies affecting the output growth rate. Column (4.5) shows the results when the overall output growth rate GY is replaced by the growth rate of private sector output (GYP). Private sector output is not directly affected by government spending and taxation, but only indirectly via the derived effects on private sector activity. Clearly, this does not eliminate possible endogeneity and GYP is therefore instrumented as before. The introduction of GYP into the fiscal balance reaction function results in very little change for eurozone countries, but the coefficient to GYP. $E$ is only $2 / 3$ of the size of the estimate to GY.E in (4.1). The counter-cyclicality of fiscal policies for the CEE countries appears to be less pronounced when private sector growth is used instead of total output growth. ${ }^{12}$ This may partly reflect the fact that GYP exhibits more variability than GY. The implausibly large coefficient to DEBT(-1) for the CEE coun-

\footnotetext{
${ }^{11}$ OLS fixed effects estimation is chosen, as GY is the fiscal stance measure and trend growth varies across countries. It also implies that the results are comparable to those of the Arellano-Bond GMM estimations in (4.1)-(4.2). Furthermore, a Hausman test rejects the null hypotheses that the individual effects are uncorrelated with the other explanatory variables in the model.

${ }^{12}$ This result may be an indirect indication that counter-cyclical policies are most effective in the CEE countries. This result is indeed confirmed in Section 4.
} 
tries is related to the lower estimate for GYP for this group of countries; the two explanatory variables are correlated with a correlation coefficient equal to 0.52 .

We also examined the consequences of using a measure for the level of the output gap (instead of the change as proxied by GY). Retaining the assumption of constant trend growth equal to average growth, the output gap level was calculated as accumulated changes in output gaps during the period 1995-2005. (This measure is clearly subject to an "endpoint problem".) The qualitative results were as before (not shown), although the difference between the coefficients to the cyclical measure across the eurozone and the CEE countries were smaller than found in (4.1).

The choice of country groups was discussed above. The estimation of reaction curves for each country gives relatively few significant coefficients and any inference is generally unreliable. Instead, each of the two country groups was divided into two subgroups. The eurozone countries were divided into southern eurozone countries (Portugal, Spain, Italy and Greece) and the remainder. The CEE countries were divided into the Baltic States (Estonia, Latvia and Lithuania) and the remainder. Regression (4.1) was then repeated with separate coefficients for BAL(-1), GY and DEBT(-1) for each of the four country groups. The results (not shown) indicate that the division into two main groups, the eurozone countries and the CEE countries, is indeed sensible. By means of example, the estimated coefficient for BAL(-1) is 0.74 for the northern, and 0.57 for the southern eurozone countries, while it is 0.22 for the Baltic States and 0.12 for the remaining CEE countries. ${ }^{13}$ A Chow test indicates that restricting the coefficients so they are identical across the two subgroups cannot be rejected at the $1 \%$ level.

\subsection{Debt, interest payments}

The estimations in Table 4 generally suggest that the debt stock has little or no effect on the overall budget balance. A possible explanation is that while a higher debt stock leads to higher interest payments that directly strain the budget, it also provides incentives to tighten fiscal policy. These two effects may outweigh each other, a view which is supported by the estimations presented in this subsection.

In Table 5, column (5.1) is repeated from (4.1) in Table 4 in order to ease comparisons with the following results. Column (5.2) shows the result when interest payments are added to regression (4.1), i.e. the overall budget balance is regressed on its lagged value, output growth, the lagged debt stock and the interest payments. Neither the lagged debt stock nor interest payments attain significant coefficients.

To assess the relative importance of direct and indirect effects on the fiscal balance from debt and interest payments, we estimated policy reaction functions explaining the primary budget balance as a percentage of GDP (PrBAL). Column (5.3) shows the results for when the primary balance is regressed on the lagged primary balance, economic growth and lagged debt stock. The results with respect to inertia and cyclicality are qualitatively unchanged. The coefficient for the debt stock is insignificant for both the eurozone and the CEE countries. ${ }^{14}$

\footnotetext{
${ }^{13}$ The only exception is an implausibly large coefficient for DEBT(-1) for the Baltic States. The small size of the subgroup and the very low debt levels make us discount this result as a statistical aberration.

${ }^{14}$ Although the estimated coefficients are insignificant, the point estimates of around 4\% appear reasonable. Ballabriga \& Martinez-Mongay (2003) and Wyplosz (2006), who use longer samples extending back to the 1980s, find that the debt stock has a positive impact on the primary balance.
} 
Table 5. Budget balance reaction functions - debt and interest payments

\begin{tabular}{|c|c|c|c|c|}
\hline & $(5.1)$ & $(5.2)$ & $(5.3)$ & $(5.4)$ \\
\hline & BAL & BAL & PrBAL & PrBAL \\
\hline \multirow{2}{*}{ BAL $(-1) \cdot W$} & $0.606 * * *$ & $0.588 * * *$ & \multirow[t]{2}{*}{.. } & \multirow{2}{*}{.. } \\
\hline & $(0.141)$ & $(0.156)$ & & \\
\hline \multirow{2}{*}{ BAL $(-1) \cdot E$} & 0.099 & 0.023 & \multirow[t]{2}{*}{.. } & \multirow[t]{2}{*}{..} \\
\hline & $(0.131)$ & $(0.101)$ & & \\
\hline \multirow{2}{*}{$\operatorname{PrBAL}(-1) \cdot W$} & \multirow[t]{2}{*}{.. } & \multirow[t]{2}{*}{..} & $0.503 * * *$ & $0.547 * * *$ \\
\hline & & & $(0.146)$ & $(0.127)$ \\
\hline \multirow{2}{*}{$\operatorname{PrBAL}(-1) \cdot E$} & \multirow[t]{2}{*}{.$\cdot$} & \multirow[t]{2}{*}{.$\cdot$} & 0.129 & 0.120 \\
\hline & & & $(0.122)$ & $(0.121)$ \\
\hline \multirow{2}{*}{$\mathbf{G Y} \cdot \boldsymbol{W}$} & $0.218 * *$ & $0.156^{*}$ & 0.085 & 0.125 \\
\hline & $(0.093)$ & $(0.086)$ & $(0.105)$ & $(0.076)$ \\
\hline \multirow{2}{*}{$\mathbf{G Y} \cdot \boldsymbol{E}$} & $0.622 * * *$ & $0.532 * * *$ & $0.655 * * *$ & $0.525 * * *$ \\
\hline & $(0.146)$ & $(0.142)$ & $(0.120)$ & $(0.106)$ \\
\hline \multirow{2}{*}{$\operatorname{DEBT}(-1) \cdot W$} & -0.013 & -0.012 & 0.041 & -0.0065 \\
\hline & $(0.022)$ & $(0.020)$ & $(0.040)$ & $(0.017)$ \\
\hline \multirow{2}{*}{$\operatorname{DEBT}(-1) \cdot E$} & 0.014 & 0.058 & 0.041 & 0.053 \\
\hline & $(0.030)$ & $(0.051)$ & $(0.047)$ & $(0.038)$ \\
\hline \multirow{2}{*}{ INTR·W } & \multirow[t]{2}{*}{.. } & -0.028 & \multirow[t]{2}{*}{.. } & $0.393 * *$ \\
\hline & & $(0.142)$ & & $(0.197)$ \\
\hline \multirow{2}{*}{ INTR $\cdot E$} & \multirow[t]{2}{*}{.$\cdot$} & -0.213 & \multirow[t]{2}{*}{.. } & 0.287 \\
\hline & & $(0.371)$ & & $(0.404)$ \\
\hline Country dummies & Yes & Yes & Yes & Yes \\
\hline Year dummies & Yes & Yes & Yes & Yes \\
\hline Method & $\mathrm{GMM}^{-\mathrm{AB}^{\mathrm{a}}}$ & $\mathrm{GMM}^{-\mathrm{AB}^{\mathrm{b})}}$ & $\mathrm{GMM}^{-\mathrm{AB}^{\mathrm{c})}}$ & $\mathrm{GMM}^{-\mathrm{AB}^{\mathrm{d}}}$ \\
\hline Time sample & $95-05$ & $95-05$ & $95-05$ & $95-05$ \\
\hline No. of countries & 22 & 22 & 22 & 22 \\
\hline No. of obs. & 194 & 189 & 186 & 186 \\
\hline \multicolumn{5}{|c|}{$\begin{array}{l}\text { Notes: White's period robust standard errors are shown in brackets below the coefficient estimates. A post-positioned } * * *, * * \text { or } * \\
\text { indicates that the null hypothesis of the coefficient being } 0 \text { is rejected at, respectively, the } 1 \%, 5 \% \text { and } 10 \% \text { confidence level. } \\
\text { a) The level instruments are BAL(-2), GY(-2) and DEBT(-2). The time-differenced instruments are output growth in the USA, output } \\
\text { growth in Russia, real oil price growth, and the real Fed funds interest rate. The instruments are included separately for the } W \text { and } E \\
\text { groups. Year dummies are also used as level instruments. } \\
\text { b) As in a) but INTR(-2) is added as level instrument. } \\
\text { c) As in a) but BAL(-2) is replaced by PrBAL(-2). } \\
\text { d) As in b) but BAL(-2) is replaced by PrBAL(-2). }\end{array}$} \\
\hline
\end{tabular}

Column (5.4) shows the results for when the actual interest payment as a percentage of GDP (INTR) is added as a regressor in the primary balance reaction function. The debt stock is still without importance. The coefficient for the interest payments is significant at the $5 \%$ level for the eurozone countries, while it remains insignificant for the CEE countries. The coefficient estimate for INTR is around 0.4, implying that if interest payments increase by $1 \%$-point of GDP, then the primary balance is strengthened by $0.4 \%$-points of GDP. In other words, higher interest payments are only partly translated into an improved primary balance in eurozone countries. The coefficient for INTR is insignificant for the CEE countries, possibly reflecting that the debt stock and hence interest payments are relatively small there.

The estimations presented in Table 5 show that the primary balance does not react to debt accumulation, but to the obligations of servicing the debt and then only significantly so for the eurozone countries. The headline budget balance appears to be unaffected by debt accumulation and interest payments. This lack of feedback suggests that there are no direct mechanisms ensuring convergence towards low levels of government debt. 


\subsection{Sample split and structural change}

The time sample used hitherto is 11 years (and shorter in some cases where the data is lacking). The relatively short sample period has the advantage of making major fiscal policy regime changes less likely within the sample. Still, during the period from 1995 to 2005 a number of events took place making it relevant to check for possible structural breaks along the time dimension. For the eurozone countries, the introduction of the euro may have affected domestic fiscal policies. For the CEE countries, the Russian crisis in the fall of 1998 was an important event that upset their economies in numerous ways.

To assess whether the formation of fiscal policy changed during the period 1995-2005, we have split the sample into two sub-periods, i.e. 1995-2000 and 2001-2005. The small sample sizes suggest that the results should be interpreted with caution. For each sub-period the fiscal balance reaction function is estimated both with and without time dummies; the latter option preserves degrees of freedom. The results are shown in Table 6. Columns (6.1) and (6.2) repeat (4.1) and (4.2) from Table 4, i.e. the regressions for the full sample with and without time dummies.

Table 6. Budget balance reaction functions - sample split and structural change

\begin{tabular}{|c|c|c|c|c|c|c|}
\hline & $(6.1)$ & $(6.2)$ & $(6.3)$ & $(6.4)$ & $(6.5)$ & $(6.6)$ \\
\hline & BAL & BAL & BAL & BAL & BAL & BAL \\
\hline \multirow{2}{*}{ BAL $(-1) \cdot W$} & $0.606 * * *$ & $0.725 * * *$ & $0.539 * * *$ & $0.842 * * *$ & $0.705 * * *$ & 0.356 \\
\hline & $(0.141)$ & $(0.052)$ & $(0.117)$ & $(0.089)$ & $(0.211)$ & $(0.248)$ \\
\hline \multirow{2}{*}{ BAL $(-1) \cdot E$} & 0.099 & $0.084 *$ & 0.071 & 0.020 & -0.012 & -0.014 \\
\hline & $(0.131)$ & $(0.092)$ & $(0.305)$ & $(0.257)$ & $(0.159)$ & $(0.172)$ \\
\hline \multirow{2}{*}{$\mathbf{G Y} \cdot \boldsymbol{W}$} & $0.218 * *$ & $0.189 *$ & 0.025 & $-0.113 *$ & 0.771 & $0.511 * * *$ \\
\hline & $(0.093)$ & $(0.104)$ & $(0.068)$ & $(0.069)$ & $(0.276)$ & $(0.173)$ \\
\hline \multirow{2}{*}{$\mathbf{G Y} \cdot \boldsymbol{E}$} & $0.622 * * *$ & $0.593 * * *$ & 0.204 & 0.224 & 0.751 & $0.946 * *$ \\
\hline & $(0.146)$ & $(0.135)$ & $(0.265)$ & $(0.211)$ & $(0.334)$ & $(0.351)$ \\
\hline \multirow{2}{*}{$\operatorname{DEBT}(-1) \cdot W$} & -0.013 & 0.0090 & -0.031 & -0.064 & -0.048 & 0.081 \\
\hline & $(0.022)$ & $(0.028)$ & $(0.032)$ & $(0.041)$ & $(0.068)$ & $(0.069)$ \\
\hline \multirow{2}{*}{$\operatorname{DEBT}(-1) \cdot E$} & 0.014 & 0.034 & 0.044 & 0.036 & 0.032 & 0.041 \\
\hline & $(0.030)$ & $(0.027)$ & $(0.067)$ & $(0.051)$ & $(0.074)$ & $(0.076)$ \\
\hline Country dummies & Yes & Yes & Yes & Yes & Yes & Yes \\
\hline Year dummies & Yes & No & Yes & No & Yes & No \\
\hline Method & GMM-AB ${ }^{a)}$ & GMM-AB $^{\text {a) }}$ & GMM-AB ${ }^{a)}$ & GMM-AB ${ }^{\text {a) }}$ & GMM-AB $^{\text {a) }}$ & GMM-AB $^{\text {a) }}$ \\
\hline Time sample & $95-05$ & $95-05$ & $95-00$ & $95-00$ & $01-05$ & $00-05$ \\
\hline No. of countries & 22 & 22 & 22 & 22 & 22 & 22 \\
\hline No. of obs. & 194 & 194 & 86 & 86 & 108 & 108 \\
\hline $\begin{array}{l}\text { Notes: White's period } \\
\text { indicates that the null } \mathrm{h} \\
\text { a) The level instruments } \\
\text { growth in Russia, real }\end{array}$ & $\begin{array}{l}\text { ust standard erro } \\
\text { thesis of the coe } \\
\text { BAL(-2), GY(-2 }\end{array}$ & $\begin{array}{l}\text { is are shown in } \\
\text { fficient being } 0 \mathrm{i}\end{array}$ & $\begin{array}{l}\text { ckets below th } \\
\text { ejected at, respe } \\
\text { he time-differe }\end{array}$ & $\begin{array}{l}\text { oefficient estim } \\
\text { vely, the } 1 \%, 5 \\
\text { ed instruments }\end{array}$ & $\begin{array}{l}\text { es. A post-posit } \\
\text { and } 10 \% \text { confid } \\
\text { output growth i }\end{array}$ & $\begin{array}{l}\text { ned } * * *, * * \text { or } * \\
\text { ace level. } \\
\text { the USA, outpu }\end{array}$ \\
\hline
\end{tabular}

When comparing (6.3)-(6.6) with (6.1)-(6.2), it follows that it is difficult to obtain satisfactory estimation results for fiscal balance reactions when the two sub-samples are estimated separately. The number of available observations is very small and this precludes formal empirical testing. It is apparent, however, that the coefficient for BAL(-1) remains larger for the eurozone 12 countries than for the CEE 10 countries in both sub-samples. This suggests that the 
policy inertia for the entire sample from 1995 to 2005 remains more pronounced in the group of eurozone countries than in the group of new EU members from Central and Eastern Europe.

The coefficients for the economic cycle in the two groups of countries are generally imprecisely estimated. Still, while the coefficient for GY. $W$ is insignificant in the first sub-period, it is sizeable and significant in the second sub-period, when the period dummies are suppressed. This would suggest that while in the second half of the 1990s fiscal policy was a-cyclical in the eurozone countries, it became counter-cyclical in the years after the turn of the century. This result is basically in line with Wyplosz (2006) who finds that fiscal policies have become more counter-cyclical in the eurozone countries since the formation of the EMU. ${ }^{15}$ The reason for this change is not immediately clear. One possibility is that the countries seeking to qualify for EMU membership abstained from pursuing counter-cyclical fiscal policies. After having secured membership, the policy priorities shifted towards cyclical accommodation.

\subsection{Expenditure and revenue reactions}

We now proceed to estimate separate fiscal policy reaction functions for general government expenditure and revenue as a percentage of GDP. The expenditure and revenue are modelled as functions of their lagged values, output growth and the lagged debt stock. The results are shown in Table 7.

Turning first to the general government expenditure as a percentage of GDP, it follows from (7.1) that the expenditure reaction function exhibits only slightly more inertia in the current eurozone countries than in future members. Expenditure are counter-cyclical in the sense that an output increase does not lead to a proportional increase in expenditure; the countercyclicality is more pronounced in the CEE countries than in the Eurozone 12 countries, although the difference is not statistically significant. The debt variable enters significantly for the CEE countries, but the result stems mainly from Slovakia, which pursued a stop-go fiscal policy in parts of the sample period. Removing Slovakia from the sample would make the coefficient for DEBT(-1) $W$ insignificant without affecting the other results qualitatively.

The revenue reaction function is shown in (7.2). Revenue as a percentage of GDP exhibits substantial inertia for both the eurozone and the CEE countries. The estimated coefficient for $\mathrm{GY} \cdot W$ is negative and estimated precisely. This indicates that revenue are pro-cyclical in the sense that higher growth is associated with lower revenue as a percentage of GDP. This result may be surprising as the bulk of revenue stems from taxes; for the progressive parts of the tax system, the tax intake as a percentage of GDP would increase when GDP increases. Mayes \& Viren (2005), using data from the old EU members, find that government revenue are more responsive to decreasing than to increasing growth rates; recessions lead to lower government revenue, while booms do not lead to corresponding increases in government revenue. (This would be the result if policymakers cut tax rates in booms when tax revenue would otherwise increase.) The coefficient for output growth is positive, but insignificant for the CEE countries. A Wald test confirms that the coefficients for $G Y \cdot W$ and GY.E are significantly different at the $5 \%$ level.

\footnotetext{
${ }^{15}$ Gali \& Perotti (2003) also find that fiscal policies have become more counter-cyclical in the post-Maastricht period.
} 
Table 7. Expenditure and revenue reaction functions

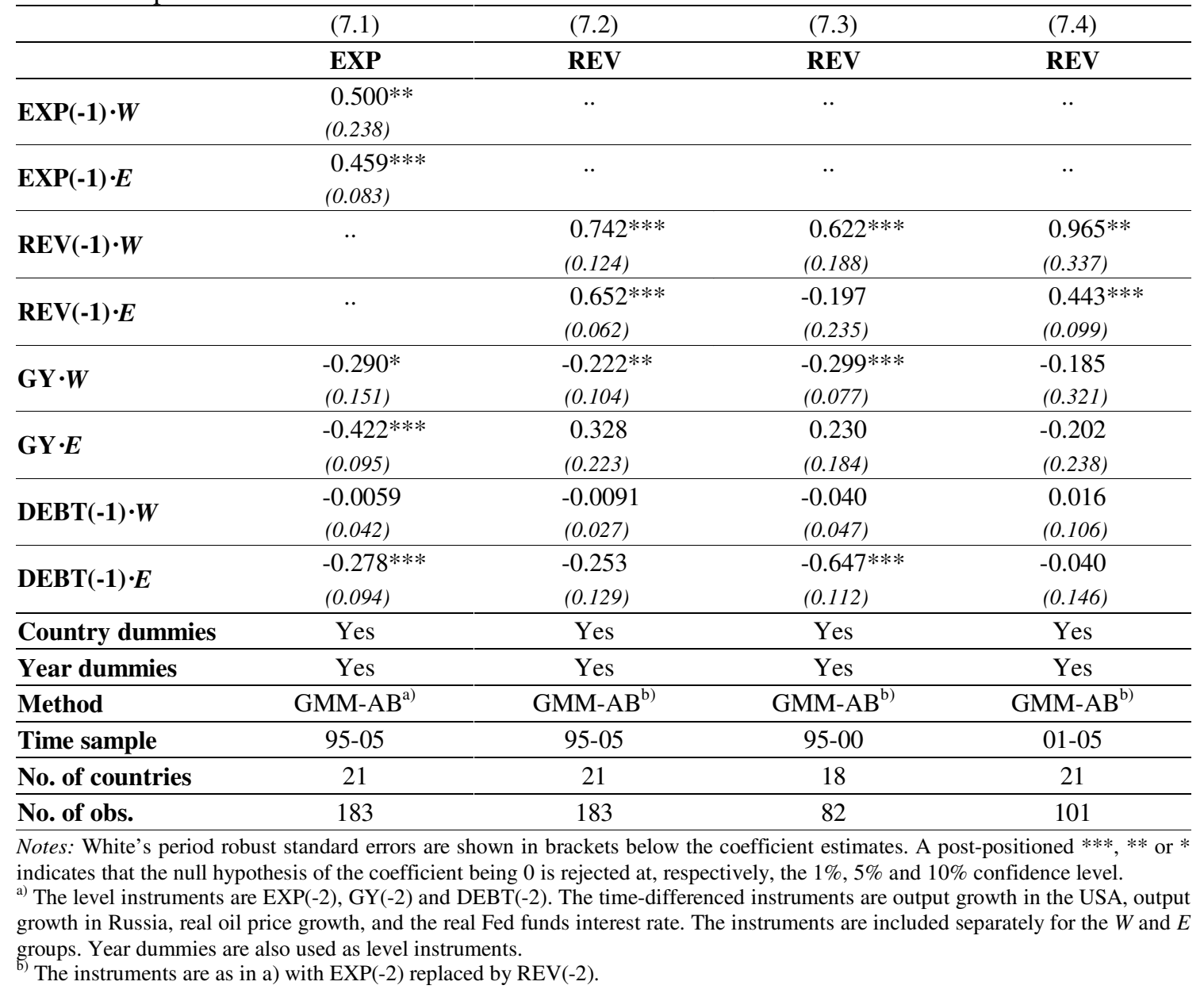

These results give some insight into the results for the budget balance found previously and in particular into the variations in the responsiveness of the budget balance to output shocks in the two country groups. For the CEE countries, a positive growth shock decreases expenditure and increases revenue as a percentage of GDP (although the effect on revenue is imprecisely estimated). The net effect is a marked improvement of the budget balance. In the case of eurozone countries, a negative output shock decreases expenditure, but also decreases revenue as a percentage of GDP. The net effect on the budget balance (in terms of a percentage of GDP) is therefore muted as found in, for example, (4.1). In other words, the lack of countercyclicality in the budget balance in the eurozone countries stems from the revenue side, not the expenditure side.

Columns (7.3) and (7.4) show the results when the sample period is divided into two subperiods. The estimations show that for the eurozone countries the negative effect of output growth on revenue as a percentage of GDP is strongest for the early part of the sample, i.e. the period before and immediately after the introduction of the euro. This finding corresponds with the observed changes in the budget balance reaction function reported in Table 6. 


\section{The impact of fiscal policy on output variability}

This section considers how different measures of fiscal policy affect output variability in the sample countries and also whether there are differences across current and future eurozone members. We derive a number of fiscal policy measures and examine their ability to explain output variability while controlling for other factors affecting output variability. As usual, the challenge is to deal adequately with the endogeneity problem, i.e. to identify respectively the effects of economic fluctuations on fiscal policy and the effects of fiscal policy on the cycle.

In this section, Denmark, Sweden, United Kingdom, Malta and Cyprus are included in the analyses. The main reason for this is that the exercises apply cross-section estimations and the additional observations improve the efficiency of the estimations. We found in (4.4) in Table 4 that inclusion of these five non-transition and non-euro countries did not alter the budget reaction functions markedly.

We will employ a total of five different country-specific fiscal policy measures. Three of the measures are averages of statistical variables and do not require much explanation. EBAL is the average general government budget balance over the period 1995-2005. EPrBAL is the average primary budget balance over the same period. EREV is the average general government revenue intake over the period 1995-2005.

In Section 3, we estimated fiscal policy reaction functions and interpreted the estimated coefficient(s) to the output growth rate as a measure of the cyclicality (or reactivity) of fiscal policy; cf. also Fatas \& Mihov (2001). In particular, Tables 4 and 5 reported estimated reaction functions for the budget balance. In this case, a positive coefficient for the output term is taken to mean that fiscal policy is counter-cyclical - the larger the coefficient, the more counter-cyclical the policy. Thus, the estimated coefficients for the output growth term can be interpreted as a measure of the degree of fiscal balance counter-cyclicality. ${ }^{16}$ It followed from Tables 4 and 5 that the budget balance on average was more counter-cyclical for the CEE countries than for the eurozone countries.

To derive a country-specific measure of the counter-cyclicality of the fiscal balance, we use our panel dataset to estimate a budget balance reaction function along the lines of the regressions in Table 4, but with country-specific coefficients for GY. The coefficient for the lagged balance is estimated separately for non-transition and the CEE countries, while the debt term is suppressed in order to retain as many degrees of freedom as possible. ${ }^{17}$

The estimation is undertaken using the Arellano-Bond GMM methodology with the instruments being the levels of the lagged endogenous variable treated separately for Western and Eastern Europe, the two periods lagged and differenced GY for each country and the time dummies. Evidently, the large number of coefficients implies that some of the coefficients are imprecisely estimated. Still, the coefficients estimated for the lagged budget balance resemble those estimated in (4.4). Likewise, the averages of the coefficients for GY for non-transition and CEE countries are broadly in line with the values found in (4.4). The two (numerically)

\footnotetext{
${ }^{16}$ The coefficient partly captures the effect on the budget balance resulting from automatic stabilisers, i.e. the effect on the fiscal balance resulting from cyclical changes while keeping policy (e.g. tax rates and unemployment replacement rates) unchanged and the effect of policy changes induced by the cyclical stance.

${ }^{17}$ We have experimented with other ways of estimating the cyclicality term, e.g. estimating equations separately for each country and estimating the panel using fixed-effects OLS. Although there are substantial differences in the individual country estimates, the different sets of counter-cyclical policy coefficients are strongly correlated.
} 
largest negative coefficients are found for Spain and Greece. The variable CCF (CounterCyclical Fiscal policy) comprises the estimated coefficients for GY for the 27 countries in the sample. The average of CCF across the 27 countries is 0.38 and the standard deviation is 0.71 . The average of CCF is 0.31 for eurozone members and 0.51 for the CEE countries; these averages correspond well to the estimated coefficients for $\mathrm{GY} \cdot W$ and $\mathrm{GY} \cdot E$, respectively, in (4.4).

Finally, a measure of the non-systematic component of fiscal policy is included. We follow Fatas \& Mihov (2003a) and define the non-systematic or autonomous part of the fiscal balance as the part that cannot be predicted given the cyclical movements or easily observable control variables. ${ }^{18}$ The autonomous fiscal balance can thus be derived as the difference between the actual budget balance and the balance predicted by a reaction function. ${ }^{19}$ In particular, the variable SDAF comprises the standard deviation of the residuals from (4.4) for each country over the period 1995-2005. SDAF is our measure of autonomous fiscal policy. A low SDAF indicates that the fiscal balance has been close to the expected fiscal policy reaction and, hence, the measure of autonomous policymaking is small. A large SDAF indicates that the fiscal balance has been greatly influenced by autonomous policy changes. The average SDAF across the 27 countries in the sample is 1.58 and the standard deviation is 0.85 .

Table 8 shows the cross-section results when the standard deviation of the private output growth is regressed on control variables and variables reflecting the fiscal policy stance. The possible endogeneity of several of the explanatory variables and the fact that SDAF and CCF have been derived from an initial regression suggest that the estimations should be undertaken using instrumental variables. However, the very small sample size and the lack of obvious instruments entail that we mainly employ OLS estimation and only use IV estimation for robustness checks.

A number of control variables are included. First, the overall size of the economy is captured by the total purchasing power parity adjusted GDP of each country averaged across the period 1995-2005. Second, the openness of the economy is proxied by the squared export share averaged over the period 1995-2005. Variables capturing size and openness are also used in e.g. Fatas \& Mihov (2001, 2003) and Koskela \& Viren (2003). Finally, separate dummies for nontransition EU members and CEE countries are included.

Column (8.1) shows the results when the average budget balance EBAL is included along with the control variables. The coefficient for the size variable is negative and significant at the 5\%-level. The standard deviation of private output growth in an economy the size of the UK is, ceteris paribus, $0.7 \%$-point lower than in an economy the size of Holland, i.e. the size variable has substantial explanatory power. The coefficient for the openness variable is positive and significant. Evaluating the derivative in the average of the export shares for the 27 countries $(50.7 \%)$, it follows that an increase in the export share from $50 \%$ to $60 \%$ leads to a $0.1 \%$-point increase in private output growth volatility. The average budget balance (EBAL)

\footnotetext{
${ }^{18}$ Fatas \& Mihov (2003a) label the variable "discretionary fiscal policy", while Gali \& Perotti (2003) use the term "non-systematic discretionary fiscal policy" to emphasise that the variable solely captures the nonsystematic component of fiscal policy.

${ }_{19}$ The autonomous fiscal policy component could also have been derived as the difference between the actual budget balance and the cyclically adjusted balance as published by e.g. the OECD, IMF or EU. This method is not applicable here as historical data on the cyclically adjusted fiscal balance is not available for CEE countries. Furthermore, reliable estimates of the cyclically adjusted balance are only available with a very long lag (Buti \& Sapir 2006, Hallett et al. 2007).
} 
does not enter significantly. From (8.2) it follows that the primary budget balance (EPrBAL) also does not appear to affect output volatility in a discernable way.

Table 8. Determinants of the variability of private output growth

\begin{tabular}{|c|c|c|c|c|c|c|}
\hline & $(8.1)$ & $(8.2)$ & $(8.3)$ & $(8.4)$ & $(8.5)$ & $(8.6)$ \\
\hline & SDGYP & SDGYP & SDGYP & SDGYP & SDGYP & SDGYP \\
\hline \multirow{2}{*}{ EBAL } & 0.124 & \multirow[t]{2}{*}{.. } & \multirow[t]{2}{*}{..} & \multirow[t]{2}{*}{..} & \multirow[t]{2}{*}{.} & \multirow[t]{2}{*}{.$\cdot$} \\
\hline & $(0.126)$ & & & & & \\
\hline \multirow{2}{*}{ EPrBAL } & \multirow{2}{*}{.$\cdot$} & 0.050 & \multirow[t]{2}{*}{.. } & \multirow[t]{2}{*}{..} & \multirow[t]{2}{*}{.. } & \multirow[t]{2}{*}{..} \\
\hline & & $(0.116)$ & & & & \\
\hline \multirow{2}{*}{ SDAF } & \multirow{2}{*}{.. } & \multirow[t]{2}{*}{..} & 0.0006 & \multirow[t]{2}{*}{.. } & \multirow[t]{2}{*}{..} & 0.135 \\
\hline & & & $(0.389)$ & & & $(0.284)$ \\
\hline \multirow{2}{*}{$\mathrm{CCF}$} & \multirow[t]{2}{*}{.$\cdot$} & \multirow[t]{2}{*}{.. } & \multirow[t]{2}{*}{$\cdot}$. & -0.412 & \multirow[t]{2}{*}{.. } & 0.139 \\
\hline & & & & $(0.363)$ & & $(0.302)$ \\
\hline \multirow{2}{*}{ EREV } & \multirow[t]{2}{*}{$\cdot}$. & \multirow[t]{2}{*}{..} & \multirow[t]{2}{*}{..} & \multirow[t]{2}{*}{..} & $-0.102 * *$ & $-0.112 * *$ \\
\hline & & & & & $(0.038)$ & $(0.042)$ \\
\hline \multirow{2}{*}{ Size } & $-0.147 * *$ & $-0.146 * *$ & $-0.154 * * *$ & -0.111 & $-0.167 * * *$ & $-0.182 * *$ \\
\hline & $(0.057)$ & $(0.057)$ & $(0.046)$ & $(0.068)$ & $(0.056)$ & $(0.075)$ \\
\hline \multirow{2}{*}{ Openness } & $1.060 * *$ & $1.316^{* * *}$ & $1.297 * * *$ & $1.580 * * *$ & $0.693 *$ & 0.618 \\
\hline & $(0.497)$ & $(0.377)$ & $(0.384)$ & $(0.368)$ & $(0.452)$ & $(0.482)$ \\
\hline \multirow{2}{*}{ Constant $\cdot W$} & $2.379 * * *$ & $1.964 * * *$ & $2.098 * * *$ & $2.024 * *$ & $7.109 * * *$ & $7.450 * * *$ \\
\hline & $(0.383)$ & $(0.487)$ & $(0.676)$ & $(0.334)$ & $(0.504)$ & $(2.069)$ \\
\hline \multirow{2}{*}{ Constant $\cdot E$} & $3.544 * * *$ & $3.137 * * *$ & $3.132 * * *$ & $2.238 * * *$ & $7.476^{* * *}$ & $7.668 * * *$ \\
\hline & $(0.724)$ & $(0.583)$ & $(0.911)$ & $(0.576)$ & $(1.826)$ & $(1.944)$ \\
\hline Method & OLS & OLS & OLS & OLS & OLS & OLS \\
\hline No. of countries & 27 & 27 & 27 & 27 & 26 & 26 \\
\hline$\overline{R^{2}}$ & 0.45 & 0.41 & 0.41 & 0.44 & 0.58 & 0.59 \\
\hline
\end{tabular}

Notes: White's heteroskedastic robust standard errors are shown in brackets below the coefficient estimates. A post-positioned $* * *$, ** or * indicates that the null hypothesis of the coefficient being 0 is rejected at, respectively, the $1 \%, 5 \%$ and $10 \%$ confidence level.

Column (8.3) shows the results when the autonomous policy variable is included. The coefficient for SDAF is very imprecisely estimated and the variable clearly does help explain private output volatility. Fatas \& Mihov (2003a) find that more fiscal expenditure discretion brings about increased output volatility. Using the full set of countries in the current dataset, a corresponding result cannot be obtained. Yet, autonomous policy-making, as captured by the variable SDAF, does not help reduce volatility, either.

The variable capturing the degree of counter-cyclicality in fiscal policy (CCF) enters with the expected negative sign in (8.4), but is insignificant at conventional significance levels. It is likely, however, that the coefficient estimate is upwardly biased, as countries with large uncertainty may choose to pursue more counter-cyclical policies (Rodrik 1998, Fatas \& Mihov 2003a). We have tried to instrument CCF using per capita income, import share and the average population size (the latter chosen as population size might affect the policy making process), but the result was essentially unchanged. The chosen instruments are, however, hardly ideal.

Column (8.5) shows that the coefficient for the average revenue intake is negative and significant at the 5\%-level. This is a recurrent result in the empirical literature; similar findings using other datasets are reported in e.g. Cohen \& Follette (2000), Fatas \& Mihov (2001) and Koskela \& Viren (2003). Column (8.6) shows the results when three fiscal policy variables 
are included measuring, respectively, the autonomous policy aggressiveness, the countercyclicality of fiscal policy and the overall size of the government sector. The size of the government sector (the revenue intake) dominates the other two variables.

Table 8 may suggest another interesting result. While the CEE countries during the period 1995-2005 have on average experienced substantially more output variability than the Western European countries, the group dummies are not significantly different in, e.g. (8.5) and (8.6). Thus, the variability of output in the CEE countries can be explained by the size of their economies, their trading structure and the size of their governments. The larger variability of the CEE countries is thus unlikely to stem from post-transition effects, but is rather a result of these countries being small (in economic terms), open and with relatively small public sectors.

Table 9 presents estimations seeking to establish whether fiscal policies affect output variability differently in Western European and CEE countries. The size, openness and intercept control variables are included separately for the two groups of countries. All results should be interpreted with caution in light of the limited degrees of freedom.

Table 9. Region-specific determinants of output growth variability

\begin{tabular}{|c|c|c|c|c|c|c|}
\hline & $(9.1)$ & $(9.2)$ & $(9.3)$ & $(9.4)$ & $(9.5)$ & $(9.6)$ \\
\hline & SDGYP & SDGYP & SDGYP & SDGYP & SDGY & SDGY \\
\hline $\mathbf{S D A F} \cdot W$ & $\begin{array}{l}0.488 * * \\
(0.213)\end{array}$ & .. & .. & .. & .. & .. \\
\hline $\mathrm{SDAF} \cdot E$ & $\begin{array}{l}-0.142 \\
(0.582)\end{array}$ & .. & .. & .. & .. &.. \\
\hline $\mathbf{C C F} \cdot W$ &.. & $\begin{array}{c}0.116 \\
(0.219) \\
\end{array}$ & .. & $\begin{array}{l}0.236 \\
(0.234) \\
\end{array}$ & $\begin{array}{c}0.018 \\
(0.176) \\
\end{array}$ & .. \\
\hline $\mathrm{CCF} \cdot \mathrm{E}$ & .. & $\begin{array}{l}-1.931 * * * \\
(0.547)\end{array}$ & .. & $\begin{array}{l}-0.201 \\
(1.468) \\
\end{array}$ & $\begin{array}{l}-1.501 * * * \\
(0.374)\end{array}$ & .. \\
\hline EREV $\cdot W$ &.$\cdot$ & .. & $\begin{array}{l}-0.027 \\
(0.024)\end{array}$ & $\begin{array}{c}-0.038 \\
(0.023)\end{array}$ &.. & $\begin{array}{l}-0.030 \\
(0.024)\end{array}$ \\
\hline $\operatorname{EREV} \cdot E$ & $\cdot$. & .. & $\begin{array}{l}-0.310^{* * *} \\
(0.059)\end{array}$ & $\begin{array}{l}-0.299 * * \\
(0.121)\end{array}$ & .. & $\begin{array}{l}-0.163 * * * \\
(0.035)\end{array}$ \\
\hline Size $\cdot W$ & $\begin{array}{l}-0.117 * * \\
(0.046)\end{array}$ & $\begin{array}{l}-0.143^{* *} \\
(0.052)\end{array}$ & $\begin{array}{l}-0.139 * * * \\
(0.042)\end{array}$ & $\begin{array}{l}-0.169 * * \\
(0.060)\end{array}$ & $\begin{array}{r}-0.068 \\
(0.060)\end{array}$ & $\begin{array}{l}-0.075 \\
(0.053) \\
\end{array}$ \\
\hline $\operatorname{Size} \cdot E$ & $\begin{array}{l}-1.392 \\
(0.837) \\
\end{array}$ & $\begin{array}{r}-1.722 \\
(0.651) \\
\end{array}$ & $\begin{array}{c}0.480 \\
(0.588) \\
\end{array}$ & $\begin{array}{l}0.355 \\
(1.066) \\
\end{array}$ & $\begin{array}{l}-1.180^{* * *} \\
(0.493)\end{array}$ & $\begin{array}{l}0.276 \\
(0.347) \\
\end{array}$ \\
\hline Openness $\cdot W$ & $\begin{array}{l}1.302 * * * \\
(0.248)\end{array}$ & $\begin{array}{l}1.452 * * * \\
(0.289)\end{array}$ & $\begin{array}{l}1.344 * * * \\
(0.350)\end{array}$ & $\begin{array}{l}1.143^{* * *} \\
(0.350)\end{array}$ & $\begin{array}{l}1.578 * * * \\
(0.352)\end{array}$ & $\begin{array}{l}1.399 * * * \\
(0.412)\end{array}$ \\
\hline Openness $\cdot E$ & $\begin{array}{l}-2.905 \\
(5.797)\end{array}$ & $\begin{array}{l}0.314 \\
(4.637)\end{array}$ & $\begin{array}{l}3.498 * * \\
(1.810)\end{array}$ & $\begin{array}{l}3.575^{*} \\
(2.040)\end{array}$ & $\begin{array}{l}0.057 \\
(1.785)\end{array}$ & $\begin{array}{r}1.317 \\
(1.107) \\
\end{array}$ \\
\hline Constant $\cdot W$ & $\begin{array}{l}1.209 * * \\
(0.530)\end{array}$ & $\begin{array}{l}1.985 \text { *** } \\
(0.285)\end{array}$ & $\begin{array}{l}3.346^{* * *} \\
(1.310)\end{array}$ & $\begin{array}{l}3.892 * * * \\
(1.256)\end{array}$ & $\begin{array}{l}1.260 * * * \\
(0.351)\end{array}$ & $\begin{array}{l}2.755^{*} \\
(1.423)\end{array}$ \\
\hline Constant $\cdot E$ & $\begin{array}{l}5.212^{* *} \\
(1.877)\end{array}$ & $\begin{array}{l}5.120 * * * \\
(1.877)\end{array}$ & $\begin{array}{c}15.39 * * * \\
(2.719)\end{array}$ & $\begin{array}{l}15.08 * * * \\
(4.390)\end{array}$ & $\begin{array}{l}3.791 * * \\
(0.850)\end{array}$ & $\begin{array}{l}8.773^{* *} \\
(1.057)\end{array}$ \\
\hline Method & OLS & OLS & OLS & OLS & OLS & OLS \\
\hline No. of countries & 27 & 27 & 26 & 26 & 27 & 26 \\
\hline$\overline{R^{2}}$ & 0.51 & 0.66 & 0.80 & 0.81 & 0.70 & 0.78 \\
\hline
\end{tabular}


Column (9.1) shows that the degree of non-systematic, autonomous fiscal policy increases the variability of private output growth in Western EU countries. Although the result may be surprising, it is in accordance with the findings in the work of Mihov (2003a), where the robustness of the finding is thoroughly examined and confirmed to apply also to the high-income OECD countries. Autonomous fiscal policy appears to have no influence on growth in the CEE countries.

The variable capturing the degree of counter-cyclical fiscal policy (CCF) enters significantly and with the expected negative sign for the CEE countries, but appears to be unimportant for Western EU countries, cf. (9.2). The result that counter-cyclical fiscal policy reduces growth variability in the CEE countries survives instrumentation using the same instruments as before, albeit only at the $5 \%$ level of significance.

As expected, the coefficient for the average revenue intake is negative for both Western European and CEE countries, but it is only statistically significant for the CEE countries, cf. (9.3). In (9.4) both CCF and EREV are included; EREV is significant for the CEE countries, but not for the group of Western European countries. The fact that the inclusion of CCF and EREV simultaneously leads to CCF becoming insignificant is the result of correlation between the two variables. The correlation coefficient between the two variables is 0.20 for Western European countries, but 0.47 for the CEE countries. Thus, on average, CEE countries with a large revenue intake have pursued more counter-cyclical policies than countries with a smaller government sector. This relationship is less pronounced in the eurozone countries.

The conclusion from (9.1)-(9.4) is that counter-cyclical fiscal policies appear to reduce private growth variability in Central and Eastern European countries, but possibly not in the economies of Western Europe during the period of analysis 1995-2005. Still, the overall size of the

public sector appears to have greater explanatory power; but this may partly be the result of the short time sample leading to imprecise estimates of CCF. Overall, the small size of the sample implies that the results should be taken as indicative. Robustness checks with the inclusion of dummies for specific countries do not alter the results qualitatively. Using the coefficient estimate from (9.4), it follows that increasing the size of the government by 5\%-points of GDP will reduce the variability of private sector growth by $1.5 \%$-point in the CEE countries. This estimate is likely to constitute an upper limit, as the average standard deviation of private sector output growth is $2.6 \%$ across the entire sample and $3.4 \%$ across the CEE countries.

Columns (9.5) and (9.6) repeat the estimations in (9.2) and (9.3) with the standard deviation of total output growth instead of only private sector output growth. The estimated coefficients drop somewhat, but the qualitative results remain unchanged.

\section{Final comments}

This paper has compared the formation and effectiveness of fiscal policy in the current and future eurozone members. Considering the formation of fiscal policy, empirical analyses indicate that the average fiscal policy reaction of the $10 \mathrm{CEE}$ countries is markedly different from the fiscal reaction in the 12 eurozone countries. The results can be outlined in the following summary: 
i) The overall budget position is on average worse in the CEE countries than in the eurozone countries. Whether the pursuit of a debt-financed fiscal expansion is appropriate or not in high-growth economies such as CEE countries is an unresolved issue.

ii) The fiscal balance exhibits much less inertia in the CEE countries than in the eurozone countries. It has proven easier to adjust the budget balance in the CEE countries than in the eurozone countries. This result partly reflects that many of the eurozone countries have sustained substantial deficits for long periods of time without the national policymakers being able to correct imbalances even when risking reprimands and fines for breaching the $3 \%$ ceiling of SGP (see also Annett \& Jaeger 2004).

iii) The fiscal balance is more counter-cyclical in the CEE countries than in the eurozone countries; the difference is significant both in statistical and economic terms. This suggests that - given the same degree of output volatility - the CEE countries experience more cyclicality in the budget than the eurozone countries.

iv) The primary balance strengthens in the eurozone countries when the interest payments increase, while a similar result cannot be found for the CEE countries.

v) For both the eurozone and CEE countries, the overall budget balance is not affected by the public debt stock or interest payments. The finding that there are no direct mechanisms ensuring convergence toward lower levels of government debt suggests that the deficit ceiling of SGP is prudent.

vi) The main difference in fiscal policy reaction in the eurozone and CEE countries stems from the revenue intake. The eurozone countries have pursued pro-cyclical revenue policies, while the CEE countries have raised revenue in a counter- or a-cyclical revenue fashion.

vii) The differences between the eurozone and CEE countries may have been waning over time.

Turning now to the effectiveness of fiscal policy, the results are based on cross-section estimations with only 26 or 27 observations. A number of econometric complications imply that the results should be interpreted with caution:

viii) Autonomous or non-systematic discretionary fiscal policies have had no effect in the CEE countries, but may have aggravated economic fluctuations in the eurozone countries. Autonomous policies have not contributed to a stabilisation of the real economy.

ix) Counter-cyclical fiscal policies may have decreased private growth variability in the CEE countries, but government size is a more important factor explaining growth variability in these countries.

In conclusion, in spite of the Central and Eastern European countries having run substantial deficits since the mid-1990s, their overall fiscal policy appears to be more "agile" and counter-cyclical than that of Western Europe. Furthermore, counter-cyclical fiscal policies have likely reduced growth fluctuations. The Central and Eastern European economies are small, open and exposed to a multitude of shocks, but have still managed to attain a reasonable degree of macroeconomic stability.

The conclusions above are all framed by the short sample on which the analyses are based. The lack of data points dictated that the analyses were kept simple and parsimonious. Only 11 or fewer annual data points for each country meant that the empirical analysis could not be undertaken on an individual country level, but had to rely on panel data estimations. The joint 
determination of economic output fluctuations and fiscal stance necessitated the use of instrumentation. As usual, the results obtained will be no better than the quality of the instruments used.

Turning finally to the future accession of the Central and Eastern European countries to the EMU, there are several policy implications in this paper. First, the agile fiscal policy reactions suggest that although several of the CEE countries have or have had substantial deficits, they should not face very large problems moving their budgets towards a more sustainable position, allowing them to satisfy the Maastricht criteria on government deficits. Second, the high degree of counter-cyclicality in budget balance implies that it will be much easier for the CEE countries to satisfy the deficit criterion during booms than recessions.

Third, the relative effectiveness of counter-cyclical fiscal policy and, more broadly, government intervention in the CEE countries, may suggest that the lack of monetary autonomy after accession to the EMU will not bring about an unduly large increase in output volatility. Fiscal policies can help dampen cyclical movements from asymmetric shocks. Fourth, an active counter-cyclical fiscal policy may lead to substantial fluctuations in the budget balance across the economic cycle, which increases the risk of breaking the Stability and Growth Pact. Developments in years to come will tell whether these anticipations and concerns prove justified. 


\section{References}

Afonso, Antonio, Christiane Nickel \& Philipp Rother (2005): "Fiscal Consolidations in the Central and Eastern European Countries", European Central Bank, Working Paper, no. 473.

Afxentiou, Panos (2000): "Convergence, the Maastricht Criteria, and Their Benefits", Brown Journal of World Affairs, vol. 7, no. 1, pp. 245-254.

Aghion, Philippe \& Peter Howitt (2006): “Appropriate Growth Policy: A Unifying Framework", Journal of the European Economic Association, vol. 4, no. 2-3, pp. 269-314.

Alesina, Alberto \& Roberto Perotti (1995): "Fiscal Expansions and Adjustments in OECD Countries", Economic Policy, vol. 10, no. 21, pp. 205-248.

Alesina, Alberto \& Roberto Perotti (1997): "Fiscal Adjustments in OECD Countries: Composition and Macroeconomic Effects," Staff Papers (International Monetary Fund), vol. 44, no. 2, pp. 210-248.

Annett, Anthony \& Albert Jaeger (2004): "Europe's Quest for Fiscal Discipline”, Finance \& Development (International Monetary Fund), June, pp. 22-25.

Ardy, Brian, Iain Begg, Dermot Hodson \& Imelda Maher \& David Mayes (2006): Adjusting to EMU, Palgrave-Macmillan.

Arellano, Manuel (2003): Panel Data Econometrics, Oxford University Press.

Aschauer, David Alan (1985): "Fiscal Policy and Aggregate Demand", American Economic Review, vol. 75, no. 1, pp. 117-127.

Baldwin, Richard \& Charles Wyplosz (2004): The Economics of European Integration, New York: McGraw Hill.

Ballabriga, Fernando \& Carlos Martiniez-Mongay (2003): "Has EMU Shifted Monetary and Fiscal Policies", in Buti, Marco (ed.): Monetary and Fiscal Policies in EMU. Interactions and Coordination, Cambridge University Press, pp. 246-272.

Bayoumi, Tamim \& Silvia Sgherri (2006): “Mr Ricardo’s Great Adventure: Estimating Fiscal Multipliers in a Truly Intertemporal Model", Centre for Economic Policy Research, CEPR Discussion Paper, no. 5839.

Berger, Helge, George Kopits \& Istvan Szekely (2007): "Fiscal Indulgence in Central Europe: Loss of the External Anchor?", Scottish Journal of Political Economy, vol. 54, no. 1, pp. 118-37.

Blanchard, Olivier \& Roberto Perotti (2002): "An Empirical Characterization of the Dynamic Effects of Changes in Government Spending and Taxes on Output", Quarterly Journal of Economics, vol. 117, no. 4, pp. 1329-1368.

Budina, Nina \& Sweder van Wijnbergen (1997): "Fiscal Policies in Eastern Europe", Oxford Review of Economic Policy, vol. 13, no. 2, pp. 47-64.

Buti, Marco \& Andre Sapir (2006): "Fiscal Policy in Europe: The Past and Future of EMU Rules from the Perspective of Musgrave and Buchanan", Centre for Economic Policy Research, CEPR Discussion Paper, no. 5830. 
Caldara, Dario \& Christophe Kamps (2006): "What do we know about the effects of fiscal policy shocks? A VAR-based comparative analysis", Computing in Economics and Finance 2006 (Society for Computational Economics), Working Paper, no. 257, http://ideas.repec.org/p/sce/scecfa/257.html

Cohen, Darrel \& Glenn Follette (2000): “The Automatic Fiscal Stabilizers: Quietly Doing Their Thing", FRBNY Economic Policy Review, April, pp. 35-68.

European Commission (2006): "The Stability and Growth Pact", website with links to legal texts, http://ec.europa.eu/economy_finance/about/activities/sgp/sgp_en.htm.

Eurostat (2006): "Statistics in Focus", http://ec.europa.eu/eurostat/. (Data downloaded $1 \mathrm{Au}$ gust 2006.)

Fatas, Antonio \& Ilian Mihov (2001): "Fiscal Policy and Business Cycles: An Empirical Investigation", http://faculty.insead.edu/fatas/myc.pdf. (Published in Spanish in Moneda y Credito, vol. 118.)

Fatas, Antonio \& Ilian Mihov (2003a): "The Case for Restricting Fiscal Policy Discretion", Quarterly Journal of Economics, vol. 118, no. 4, pp. 1419-1447.

Fatas, Antonio \& Ilian Mihov (2003b): "On restricting fiscal policy in EMU”, Oxford Review of Economic Policy, vol. 19, no. 1, pp. 112-131.

Fatas, Antonio \& Ilian Mihov (2005): "Policy Volatility, Institutions and Economic Growth", Centre for Economic Policy Research, CEPR Discussion Paper, no. 5388.

Fischer, Stanley (1993): "The Role of Macroeconomic Factors in Growth", Journal of Monetary Economics, vol. 32, no. 3, pp. 485-512.

Frankel, Jeffrey \& Andrew Rose (1998): “The Endogeneity of the Optimum Currency Area Criteria", Economic Journal, vol. 108, no. 449, pp. 1009-1025.

Frenkel, Michael \& Christiane Nickel (2005): "How Symmetric Are the Shocks and the Shock Adjustment Dynamics between the Euro Area and Central and Eastern European Countries?", Journal of Common Market Studies, vol. 43, no. 1, pp. 53-74.

Gali, Jordi \& Roberto Perotti (2003): "Fiscal policy and monetary integration in Europe", Economic Policy, vol. 18, no. 37, pp. 533-572.

Green, William (2000): Econometric Analysis, Prentice Hall, $4^{\text {th }}$ ed.

Grigonyte, Dalia (2003): "Impact of Currency Boards on Fiscal Policy in Central and Eastern European Countries”, Economics of Planning, vol. 36, no. 2, pp. 111-133.

Hallett, Andrew, Rasmus Kattai \& John Lewis (2007): "Early Warning or Just Wise After the Event? The Problem of Using Cyclically Adjusted Budget Deficits for Fiscal Surveillance", Bank of Estonia, Working Paper, no. 2/2007.

Judson, Ruth \& Ann Owen (1999): "Estimating Dynamic Panel Data Models: A Practical Guide for Macroeconomists', Economic Letters, vol. 65, no. 1, pp. 9-15.

Kattai, Rasmus \& John Lewis (2005): "Hooverism, Hyperstabilisation or Halfway-House? Describing Fiscal Policy in Central and Eastern European EU Countries", Baltic Journal of Economics, vol. 6, no. 1. 
Korhonen, Iikka (2003): "Some empirical tests on the integration of economic activity between the euro area and the accession countries", Economics of Transition, vol. 11, no. 1, pp. 177-196.

Koskela, Erkki \& Matti Viren (2003): “Government Size and Output Volatility: New International Evidence", University of Helsinki, Department of Economics, Discussion Paper, no. 569.

Mayes, David \& Matti Viren (2005): "The SGP and The ECB: An Exercise in Asymmetry", paper for the conference "Economic Consequences of European Monetary Integration", University of Victoria, 18-19 August, www.sinica.edu.tw/econ/activities/past/ 20050927.pdf.

Mueller, Johannes, Christian Beddies, Robert Burgess, Vitali Kramarenko \& Joannes Mongardini (2002): "The Baltic Countries: Medium-Term Fiscal Issues Related to EU and NATO Accession”, Occasional Paper (International Monetary Fund), no. 213.

Murray, Michael (2006): "Avoiding Invalid Instruments and Coping with Weak Instruments", Journal of Economic Perspectives, vol. 20, no. 4, pp. 111-132.

Nuti, Mario (2006): “Alternative Fiscal Rules for the New EU Member States", TIGER Working Paper (Warsaw), no. 84.

Perotti, Roberto (2005): "Estimating the Effects of Fiscal Policy in OECD Countries", CEPR Discussion Paper, no. 4842.

Rodrik, Dani (1998): “Why do More Open Economies Have Bigger Governments?”, Journal of Political Economy, vol. 106, no. 5, pp. 997-1032.

Romer, David (2005): Advanced Macroeconomics, McGraw-Hill.

Roubini, Nouriel \& Jeffery Sachs (1989): "Political and Economic Determinants of Budget Deficits in the Industrial Democracies", European Economic Review, vol. 33, no. 5, pp. 903-938.

Wyplosz, Charles (2002): "Fiscal Policy: Institutions vs. Rules", The Graduate Institute of International Studies, Geneva, HEI Working Paper, no. 03/2002.

Wyplosz, Charles (2006): "European Monetary Union: The Dark Sides of a Major Success", Economic Policy, vol. 21, no. 46, pp. 207-261.

[All web links valid 18 January 2007.] 


\section{Appendix A}

The source of all variables is Eurostat (2006). The data was downloaded on 1 August 2006.

\section{Variables varying over time and across countries}

BAL $=$ General government budget balance, percent of GDP.

DEBT $\quad=$ General government debt, percent of GDP.

$E \quad=$ Dummy equal to 0 for the eurozone countries, the EU15 countries or the EU15 plus Malta and Cyprus (depending on context); 1 for the countries in Central and Eastern Europe.

EXP $\quad=$ General government expenditure, percent of GDP.

GY = Growth of GDP, percent year-to-year.

GYP $\quad=$ Growth of private sector GDP, percent year-to-year.

INTR = General government interest payments, percent of GDP.

PrBAL $=$ General government primary budget balance, calculated as PrBAL $=\mathrm{BAL}$ + INTR.

REV $=$ General government (tax and non-tax) revenue, percent of GDP.

$W \quad=$ Dummy equal to 1 for the eurozone countries, the EU15 countries or the EU15 plus Malta and Cyprus (depending on context); 0 for the countries in Central and Eastern Europe.

Variables varying over time (used as “outside instruments" in GMM-AB estimations)

Output growth in Russia $=$ Growth of GDP, percent year-to-year. Source: Transition Report 2005: Business in Transition, European Bank for Reconstruction and Development. Macroeconomic indicators, http://www.ebrd.com/pubs/econo/6520.htm.

Output growth in the USA $=$ Growth of GDP, percent year-to-year.

Real Fed funds interest rate $=$ Average annual Federal Funds rate minus US consumer price inflation. Sources: http://www.federalreserve.gov/ releases/h15/data.htm; IMF, International Financial Statistics (CD-rom).

Real oil price growth $\quad=$ Growth of oil price (average of three widely traded oil types) in US dollars deflated by US consumer price index. Source: IMF, International Financial Statistics (CD-rom). 
Variables varying across countries

$\mathrm{CCF}=$ Degree of Counter-Cyclicality of Fiscal balance. The country-specific CCF coefficients are obtained from a panel estimation explaining BAL by its lagged value and GY; the country-specific coefficient to GY is CCF.

CEE dummy $=$ Dummy equal to 0 for the EU15 plus Malta and Cyprus; 1 for countries in Central and Eastern Europe.

EBAL $\quad=$ Average of BAL across 1995-2005.

EPrBAL $=$ Average of PrBAL across 1995-2005.

EREV $\quad=$ Average of REV across 1995-2005.

Openness $=$ Squared value of average of export as a share of GDP across 1995-2005.

SDAF $\quad=$ Measure of autonomous policy "aggressiveness"; standard deviation of residual from (4.4) across 1995-2005.

Size $\quad=$ Product of the following two variables, i.e. the index of relative Purchasing Power Parity adjusted GDP per capita (EU25 = 100) averaged across the years 1995-2005 and the average population across 1995-2005 in billions. 


\section{Appendix B}

Table B.1. The general government budget balance in 27 European countries, \% of GDP

\begin{tabular}{|c|c|c|c|c|c|c|c|c|c|c|c|c|}
\hline & 1995 & 1996 & 1997 & 1998 & 1999 & 2000 & 2001 & 2002 & 2003 & 2004 & $2005^{\mathrm{a})}$ & Avg. ${ }^{\text {b) }}$ \\
\hline Belgium & -4.3 & -3.8 & -2.0 & -0.7 & -0.4 & 0.2 & 0.6 & 0.0 & 0.1 & 0.0 & 0.1 & -0.9 \\
\hline Bulgaria &.. & .. & -0.3 & 1.7 & 0.4 & -0.5 & 1.4 & -0.2 & 0.6 & 1.3 & .. & 0.6 \\
\hline Czech Republic &.. &.. & -2.5 & -5.0 & -3.6 & -3.7 & -5.9 & -6.8 & -6.6 & -2.9 & -2.6 & -4.4 \\
\hline Denmark & -3.1 & -1.9 & -0.5 & 0.2 & 2.4 & 1.7 & 2.6 & 1.2 & 1.0 & 2.7 & 4.9 & 1.0 \\
\hline Germany & -3.3 & -3.4 & -2.7 & -2.2 & -1.5 & 1.3 & -2.9 & -3.7 & -4.0 & -3.7 & -3.3 & -2.7 \\
\hline Estonia &.. &.. & 1.9 & -0.3 & -3.7 & -0.6 & 0.3 & 1.0 & 2.4 & 1.5 & 1.6 & 0.5 \\
\hline Greece & -10.2 & -7.4 & -4.0 & -2.5 & -1.8 & -4.1 & -6.1 & -4.9 & -5.8 & -6.9 & -4.5 & -5.3 \\
\hline Spain & .. & -4.9 & -3.2 & -3.0 & -1.2 & -0.9 & -0.5 & -0.3 & 0.0 & -0.1 & 1.1 & -1.3 \\
\hline France & -5.5 & -4.1 & -3.0 & -2.7 & -1.8 & -1.4 & -1.6 & -3.2 & -4.2 & -3.7 & -2.9 & -3.1 \\
\hline Ireland & -2.1 & -0.1 & 1.1 & 2.4 & 2.4 & 4.4 & 0.8 & -0.4 & 0.2 & 1.5 & 1.0 & 1.0 \\
\hline Italy & -7.6 & -7.1 & -2.7 & -2.8 & -1.7 & -0.6 & -3.2 & -2.9 & -3.4 & -3.4 & -4.1 & -3.6 \\
\hline Cyprus &.. &.. & .. & -4.3 & -4.5 & -2.4 & -2.3 & -4.5 & -6.3 & -4.1 & -2.4 & -3.9 \\
\hline Latvia & .. & .. & .. & -0.6 & -4.9 & -2.8 & -2.1 & -2.3 & -1.2 & -0.9 & 0.2 & -1.8 \\
\hline Lithuania & .. & .. & -1.1 & -3.0 & -5.6 & -2.5 & -2.0 & -1.4 & -1.2 & -1.5 & -0.5 & -2.1 \\
\hline Luxembourg & 2.1 & 1.9 & 3.2 & 3.2 & 3.7 & 6.0 & 6.1 & 2.0 & 0.2 & -1.1 & -1.9 & 2.3 \\
\hline Hungary &.. &.. & -6.8 & -8.0 & -5.6 & -3.0 & -3.5 & -8.4 & -6.4 & -5.4 & -6.1 & -5.9 \\
\hline Malta &.. &.. & -10.7 & -10.8 & -7.6 & -6.2 & -6.6 & -5.6 & -10.2 & -5.1 & -3.3 & -7.3 \\
\hline Netherlands & -4.2 & -1.8 & -1.1 & -0.8 & 0.7 & 2.2 & -0.2 & -2.0 & -3.1 & -1.9 & -0.3 & -1.1 \\
\hline Austria & -5.6 & -3.9 & -1.8 & -2.3 & -2.2 & -1.5 & 0.1 & -0.5 & -1.5 & -1.1 & -1.5 & -2.0 \\
\hline Poland &.. &.. & -4.0 & -2.1 & -1.4 & -0.7 & -3.7 & -3.2 & -4.7 & -3.9 & -2.5 & -2.9 \\
\hline Portugal & -4.5 & -4.0 & -3.0 & -2.6 & -2.8 & -2.8 & -4.2 & -2.9 & -2.9 & -3.2 & -6.0 & -3.5 \\
\hline Romania & .. &.. & -4.5 & -4.4 & -2.1 & -3.8 & -3.5 & -2.0 & -2.0 & -1.4 &.. & -3.0 \\
\hline Slovenia & .. & .. & .. & -2.2 & -2.1 & -3.5 & -3.9 & -2.7 & -2.8 & -2.3 & -1.8 & -2.7 \\
\hline Slovakia &.. &.. & -5.5 & -4.7 & -6.4 & -12.3 & -6.6 & -7.7 & -3.7 & -3.0 & -2.9 & -5.9 \\
\hline Finland & -3.7 & -3.2 & -1.5 & 1.5 & 2.2 & 7.1 & 5.2 & 4.1 & 2.5 & 2.3 & 2.6 & 1.7 \\
\hline Sweden & -7.0 & -2.7 & -0.9 & 1.8 & 2.5 & 5.1 & 2.5 & -0.2 & 0.1 & 1.8 & 2.9 & 0.5 \\
\hline$\overline{\text { United Kingdom }}$ & -5.7 & -4.3 & -2.0 & 0.2 & 1.0 & 3.8 & 0.7 & -1.6 & -3.3 & -3.3 & -3.6 & -1.6 \\
\hline $\mathbf{E U 1 5}^{\mathrm{c}}$ &.. &.. &.. & -1.6 & -0.7 & 1.0 & -1.2 & -2.2 & -2.9 & -2.6 & -2.3 & -1.6 \\
\hline $\mathbf{E U 2 5}^{\mathrm{c}}$ & .. & .. & .. & -1.7 & -0.8 & 0.8 & -1.3 & -2.3 & -3.0 & -2.6 & -2.3 & -1.7 \\
\hline
\end{tabular}

a) Estimates by Eurostat.

b) Average over 1995-2005 (or available sample).

${ }^{\mathrm{c}}$ GDP weighted averages (Bulgaria and Romania are not included in EU25).

Source: Eurostat (2006). 


\section{CESifo Working Paper Series}

(for full list see www.cesifo-group.de)

1872 Hans Gersbach and Bernhard Pachl, Cake Division by Majority Decision, December 2006

1873 Gunther Schnabl, The Evolution of the East Asian Currency Baskets - Still Undisclosed and Changing, December 2006

1874 Horst Raff and Michael J. Ryan, Firm-Specific Characteristics and the Timing of Foreign Direct Investment Projects, December 2006

1875 Jukka Pirttilä and Håkan Selin, How Successful is the Dual Income Tax? Evidence from the Finnish Tax Reform of 1993, December 2006

1876 Agnieszka Stążka, Sources of Real Exchange Rate Fluctuations in Central and Eastern Europe - Temporary or Permanent?, December 2006

1877 Xavier Calsamiglia, Teresa Garcia-Milà and Therese J. McGuire, Why do Differences in the Degree of Fiscal Decentralization Endure?, December 2006

1878 Natacha Gilson, How to be Well Shod to Absorb Shocks? Shock Synchronization and Joining the Euro Zone, December 2006

1879 Scott Alan Carson, Modern Health Standards for Peoples of the Past: Biological Conditions by Race in the American South, 1873 - 1919, December 2006

1880 Peter Huber, Michael Pfaffermayr and Yvonne Wolfmayr, Are there Border Effects in the EU Wage Function?, December 2006

1881 Harry Flam and Håkan Nordström, Euro Effects on the Intensive and Extensive Margins of Trade, December 2006

1882 Panu Poutvaara and Mikael Priks, Hooliganism in the Shadow of the 9/11 Terrorist Attack and the Tsunami: Do Police Reduce Group Violence?, December 2006

1883 Ruud A. de Mooij and Gaëtan Nicodème, Corporate Tax Policy, Entrepreneurship and Incorporation in the EU, December 2006

1884 Johannes Becker and Clemens Fuest, Corporate Tax Policy and International Mergers and Acquisitions - Is the Tax Exemption System Superior?, January 2007

1885 Momi Dahan and Udi Nisan, The Effect of Benefits Level on Take-up Rates: Evidence from a Natural Experiment, January 2007

1886 José García-Solanes, Francisco I. Sancho-Portero and Fernando Torrejón-Flores, Beyond the Salassa-Samuelson Effect in some New Member States of the European Union, January 2007 
1887 Peter Egger, Wolfgang Eggert and Hannes Winner, Saving Taxes Through Foreign Plant Ownership, January 2007

1888 Timothy J. Goodspeed and Andrew Haughwout, On the Optimal Design of Disaster Insurance in a Federation, January 2007

1889 Wim Groot, Henriëtte Maassen van den Brink and Bernard van Praag, The Compensating Income Variation of Social Capital, January 2007

1890 Bas Jacobs, Ruud A. de Mooij and Kees Folmer, Analyzing a Flat Income Tax in the Netherlands, January 2007

1891 Hans Jarle Kind, Guttorm Schjelderup and Frank Stähler, Newspapers and Advertising: The Effects of Ad-Valorem Taxation under Duopoly, January 2007

1892 Erkki Koskela and Rune Stenbacka, Equilibrium Unemployment with Outsourcing under Labour Market Imperfections, January 2007

1893 Maarten Bosker, Steven Brakman, Harry Garretsen, Herman de Jong and Marc Schramm, The Development of Cities in Italy 1300 - 1861, January 2007

1894 Michel Beine, Oscar Bernal, Jean-Yves Gnabo and Christelle Lecourt, Intervention Policy of the BoJ: A Unified Approach, January 2007

1895 Robert S. Chirinko and Daniel J. Wilson, State Investment Tax Incentives: A Zero-Sum Game?, January 2007

1896 Theo S. Eicher and Oliver Roehn, Sources of the German Productivity Demise Tracing the Effects of Industry-Level ICT Investment, January 2007

1897 Helge Berger, Volker Nitsch and Tonny Lybek, Central Bank Boards around the World: Why does Membership Size Differ?, January 2007

1898 Gabriel Felbermayr and Wilhelm Kohler, Does WTO Membership Make a Difference at the Extensive Margin of World Trade?, January 2007

1899 Benno Torgler and Friedrich Schneider, The Impact of Tax Morale and Institutional Quality on the Shadow Economy, January 2007

1900 Tomer Blumkin and Efraim Sadka, On the Desirability of Taxing Charitable Contributions, January 2007

1901 Frederick van der Ploeg and Reinhilde Veugelers, Higher Education Reform and the Renewed Lisbon Strategy: Role of Member States and the European Commission, January 2007

1902 John Lewis, Hitting and Hoping? Meeting the Exchange Rate and Inflation Criteria during a Period of Nominal Convergence, January 2007 
1903 Torben M. Andersen, The Scandinavian Model - Prospects and Challenges, January 2007

1904 Stephane Dees, Sean Holly, M. Hashem Pesaran and L. Vanessa Smith, Long Run Macroeconomic Relations in the Global Economy, January 2007

1905 Richard Jong-A-Pin and Jakob De Haan, Political Regime Change, Economic Reform and Growth Accelerations, January 2007

1906 Sascha O. Becker and Peter H. Egger, Endogenous Product versus Process Innovation and a Firm's Propensity to Export, February 2007

1907 Theo S. Eicher, Chris Papageorgiou and Oliver Roehn, Unraveling the Fortunates of the Fortunate: An Iterative Bayesian Model Averaging (IBMA) Approach, February 2007

1908 Liliana E. Pezzin, Robert A. Pollak and Barbara S. Schone, Efficiency in Family Bargaining: Living Arrangements and Caregiving Decisions of Adult Children and Disabled Elderly Parents, February 2007

1909 Christian Keuschnigg and Soren Bo Nielsen, Self-Selection and Advice in Venture Capital Finance, February 2007

1910 Rune Jansen Hagen and Gaute Torsvik, Irreversible Investments, Dynamic Inconsistency and Policy Convergence, February 2007

1911 Eric A. Hanushek and Ludger Woessmann, The Role of School Improvement in Economic Development, February 2007

1912 Bernard M. S. van Praag, Perspectives from the Happiness Literature and the Role of New Instruments for Policy Analysis, February 2007

1913 Volker Grossmann and Thomas M. Steger, Growth, Development, and Technological Change, February 2007

1914 Margarita Katsimi and Thomas Moutos, Human Capital and the Feldstein-Horioka Puzzle, February 2007

1915 Oliver Roehn, Theo S. Eicher and Thomas Strobel, The Ifo Industry Growth Accounting Database, February 2007

1916 Ian Babetskii, Aggregate Wage Flexibility in Selected New EU Member States, February 2007

1917 Burkhard Heer, Alfred Maussner and Paul D. McNelis, The Money-Age Distribution: Empirical Facts and Limited Monetary Models, February 2007

1918 Yin-Wong Cheung, Menzie D. Chinn and Eijii Fujii, The Overvaluation of Renminbi Undervaluation, February 2007 
1919 Jim Malley, Apostolis Philippopoulos and Ulrich Woitek, To React or Not? Fiscal Policy, Volatility and Welfare in the EU-3, February 2007

1920 Mattias Polborn, Competing for Recognition through Public Good Provision, February 2007

1921 Lars P. Feld and Benno Torgler, Tax Morale after the Reunification of Germany: Results from a Quasi-Natural Experiment, February 2007

1922 Robert S. Chirinko and Huntley Schaller, Fundamentals, Misvaluation, and Investment: The Real Story, February 2007

1923 Benno Torgler and Friedrich Schneider, Shadow Economy, Tax Morale, Governance and Institutional Quality: A Panel Analysis, February 2007

1924 Adrian Pagan and M. Hashem Pesaran, On Econometric Analysis of Structural Systems with Permanent and Transitory Shocks and Exogenous Variables, February 2007

1925 Hans-Werner Sinn, The Welfare State and the Forces of Globalization, February 2007

1926 Michael Smart, Raising Taxes through Equalization, February 2007

1927 Øystein Foros, Kåre P. Hagen and Hans Jarle Kind, Price-Dependent Profit Sharing as an Escape from the Bertrand Paradox, February 2007

1928 Balázs Égert, Kirsten Lommatzsch and Amina Lahrèche-Révil, Real Exchange Rates in Small Open OECD and Transition Economies: Comparing Apples with Oranges?, February 2007

1929 Aleksander Berentsen and Cyril Monnet, Monetary Policy in a Channel System, February 2007

1930 Wolfgang Ochel, The Free Movement of Inactive Citizens in the EU - A Challenge for the European Welfare State?, February 2007

1931 James K. Hammitt and Nicolas Treich, Statistical vs. Identified Lives in Benefit-Cost Analysis, February 2007

1932 Wilhelm Kohler, The Bazaar Effect, Unbundling of Comparative Advantage, and Migration, February 2007

1933 Karsten Staehr, Fiscal Policies and Business Cycles in an Enlarged Euro Area, February 2007 